\title{
Working
}

Paper 


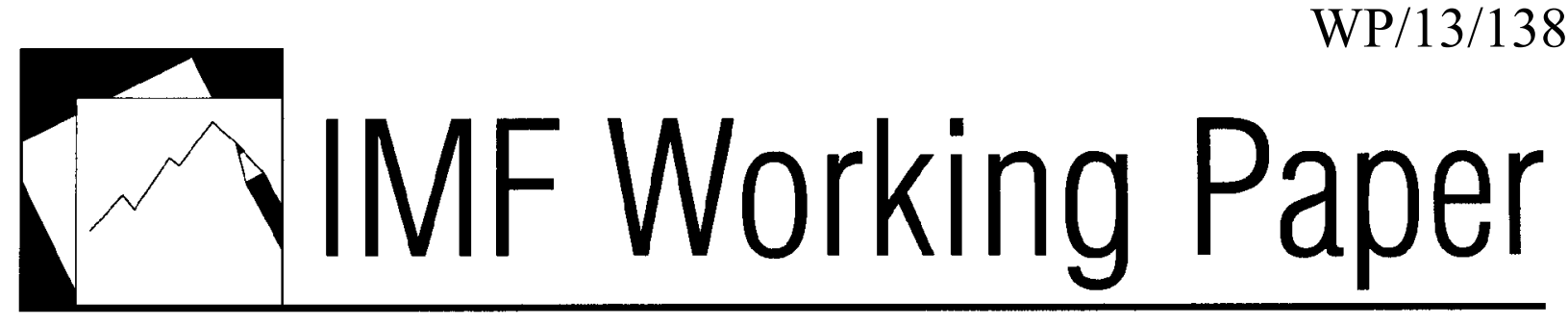

\section{The Macroeconomic Effects of Natural Resource Extraction: Applications to Papua New Guinea}

Suman Basu, Jan Gottschalk, Werner Schule, Nikhil Vellodi, and Shu-Chun S. Yang 


\title{
IMF Working Paper
}

Research Department

\section{The Macroeconomic Effects of Natural Resource Extraction: Applications to Papua New Guinea}

\author{
Prepared by Suman Basu, Jan Gottschalk, Werner Schule, Nikhil Vellodi, and Shu-Chun \\ S. Yang*
}

Authorized for distribution by Brian Aitken and Andrew Berg

0 D 2013

\section{This Working Paper should not be reported as representing the views of the IMF.}

The views expressed in this Working Paper are those of the author(s) and do not necessarily represent those of the IMF or IMF policy. Working Papers describe research in progress by the author(s) and are published to elicit comments and to further debate.

\begin{abstract}
To investigate the effects on Papua New Guinea's economy of substantial liquified natural gas revenues arriving in 2015, we employ a model to examine the macroeconomic effects of a scalingup of natural resource windfall revenues and the implications for a variety of policy responses. The model is a multi-sector dynamic stochastic general equilibrium (DSGE) model, and features components that allow for a detailed study of the effects of both fiscal and monetary policy in response to a positive shock to the mineral resource value of a country. The model contains tradable, non-tradable, and mining sectors, as well as an independent central bank and fiscal authority. We calibrate the model to the current economy of Papua New Guinea and run a suite of policy simulations. We find that macroeconomic effects from a resource boom typically associated with Dutch Disease effects such as a real appreciation and a fall in tradable sector production stem largely from the non-tradable component of government spending. The central bank can offset the real appreciation, but not without crowding out the private sector. A sovereign wealth fund (SWF), combined with a smooth capital spending path, entails the best means of dealing with macroeconomic volatility and maintaining a stable fiscal regime.
\end{abstract}

JEL Classification Numbers: Q32, E22, F43, O41

Keywords: Papua New Guinea; natural resource; resource-rich developing countries; DSGE models

Author's E-Mail Addresses: SBasu2@,imf.org, JGottschalk@imf.org, WSchule@,imf.org, n.vellodi@gmail.com, syang@imf.org

\footnotetext{
${ }^{*}$ We thank Yongzheng Yang for helpful comments.
} 


\section{Contents}

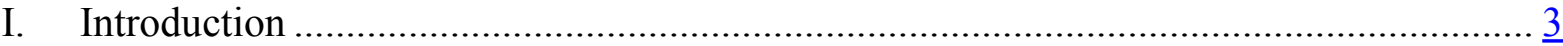

II. The Model Set-up ............................................................................................ $\frac{6}{7}$

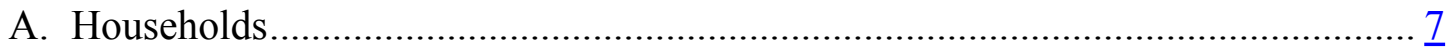

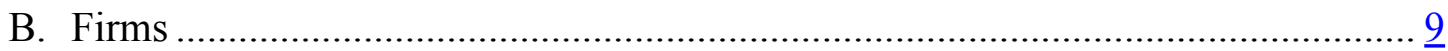

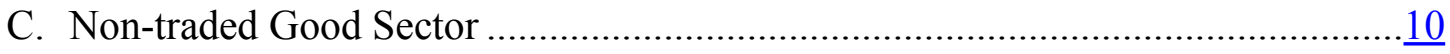

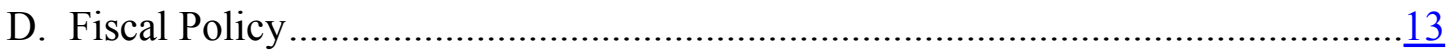

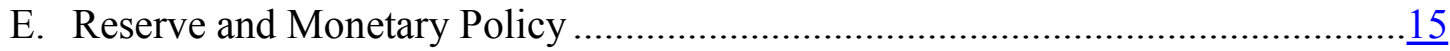

F. Aggregation and Some Identities......................................................... 16

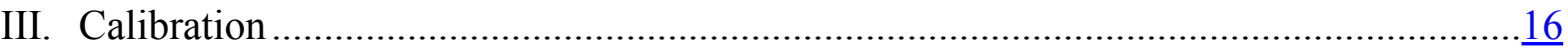

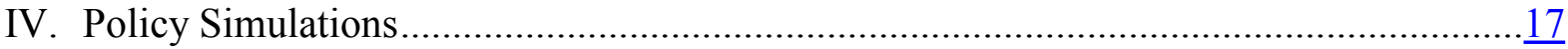

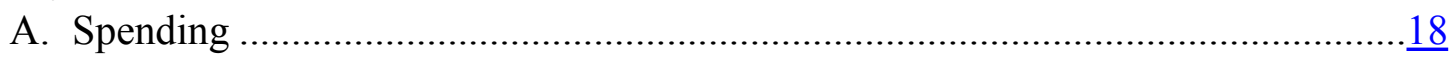

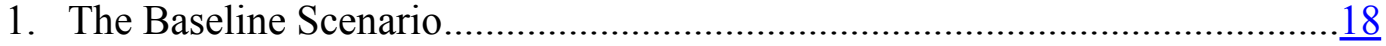

2. Inter-sectoral Spending Profile ............................................................ $\underline{20}$

3. Inter-temporal Spending Profile ...................................................... 20

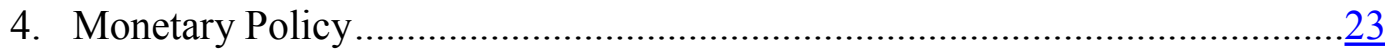

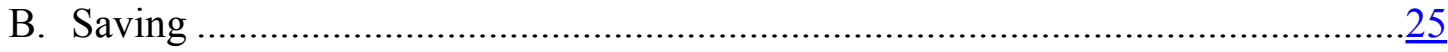

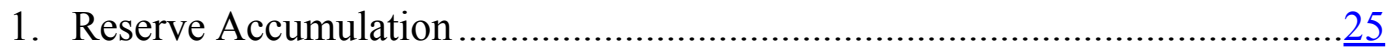

2. The Sovereign Wealth Fund ..............................................................25

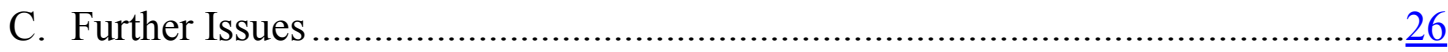

1. Current Account........................................................................... 25

2. Real Versus Nominal Exchange Rate .....................................................27

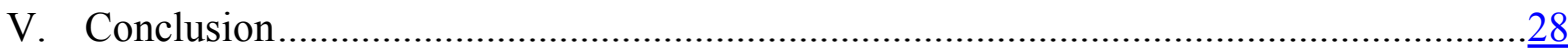

Figures

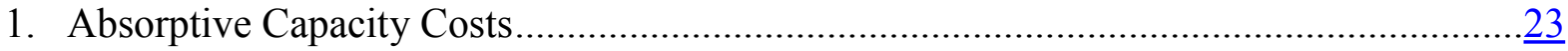

2. Baseline Scenario: Summary of Results .................................................................. $\frac{31}{32}$

3. Scenario 2: Summary of Results................................................................................ $\underline{32}$

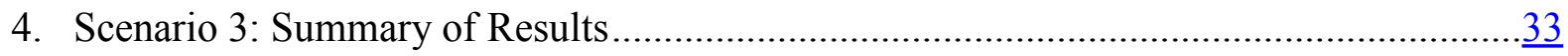

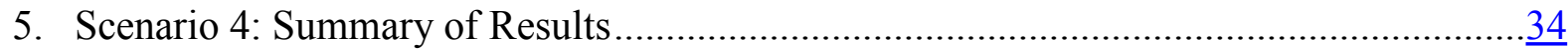

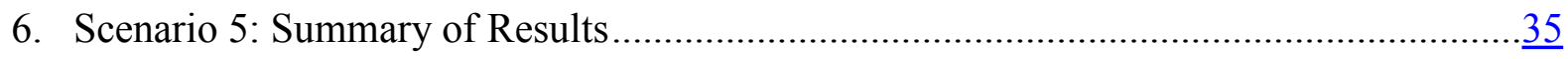

\section{Tables}

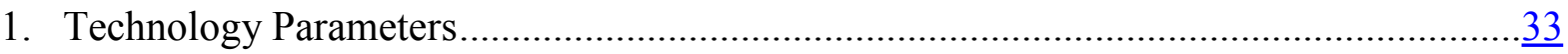

2. Preference Parameters................................................................................................... $\frac{33}{34}$

3. National Accounts Steady State Values......................................................................

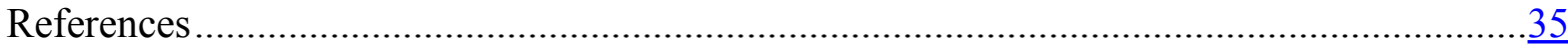

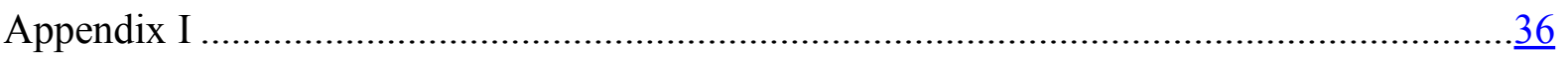




\section{INTRODUCTION}

Papua New Guinea (PNG) is currently experiencing a sizable natural resource boom. The country has been a mining-intensive economy, and as such, has experienced a positive terms-of-trade effect from the high commodity prices over the last decade. However, with the construction phase of a major Liquefied Natural Gas (LNG) project coming to a peak in 2012-13, the subsequent earnings from export receipts and dividend payments beginning approximately in 2015 are projected to be considerably higher than any previous inflows from mineral exports. ${ }^{1}$ This raises two interrelated questions. Firstly, how should these resources be used, and secondly, what are the likely macroeconomic impacts. Given that most of the LNG revenue inflows will accrue to the government, the first question is mainly one of available fiscal policy options; broadly speaking, the government can save or spend these resources, with further options available regarding the composition and timing of spending. ${ }^{2}$ The answer to the second depends largely on how fiscal policy utilizes these resources. As such, these two questions are interrelated, with key issues including the impact on inflation, output and the real exchange rate. Given the role of monetary policy in macroeconomic management, its response needs to be considered as well. The purpose of this paper is to investigate the interplay of fiscal and monetary policy options regarding LNG revenue inflows as well as the likely macroeconomic impact using a model-based analysis.

For a country like PNG that is experiencing a commodity boom, an issue of paramount importance is the so-called "natural resource curse," in which the economic development of many natural resource-rich countries does not benefit from extraction, and indeed may even suffer outright. ${ }^{3}$ Whilst this curse is a multi-faceted phenomenon, this paper will focus solely on the macroeconomic aspect. Broadly speaking, there are three macroeconomic channels through which economic development may suffer from a commodity boom such as the one PNG is experiencing now:

- The first is an unproductive use of natural resource revenue inflows. With regards fiscal policy, this could be that the government uses revenue inflows only to boost government consumption without having any lasting productive effect on the economy, at the expense of saving these resources or using them for productive public investment.

\footnotetext{
${ }^{1}$ For the purposes of simplicity, we classify oil, natural gas, and other oil derivatives as mineral exports.

${ }^{2}$ As a rough approximation, we assume that the revenues generated by the LNG project are split between the foreign investor and the government, which receives tax revenues and dividends from the project, the last reflecting its equity stake. The foreign investor is assumed to use his revenue share to pay dividends to its foreign shareholders and to service external loans taken out to finance the project; that is, revenue flows accruing to the foreign investor are assumed to be repatriated and therefore are not available to the PNG economy. In principle, households receive income from the project in the form of wages and dividends, but these flows are small and the model we use in this paper abstracts from them for simplicity. Hence, government collection of taxes and dividends are the only inflow of LNG revenues into the PNG economy in the model used here.
}

${ }^{3}$ See van der Ploeg (2011) for a detailed survey. 
- The second is a loss in external competitiveness from the rise in government consumption that damages the tradable sector in the economy. In this event, the increase in government spending would result in a real appreciation of the currency that reduces profitability of the tradable sector relative to the non-tradable sector. This would account for a decline in the tradable sector but not necessarily imply a setback to overall economic development, given that the non-tradable sector would expand.

- For overall economic development to suffer in this transmission mechanism, a third channel is potentially significant: the tradable sector must play a special role for economic development. For example, it could be the main source of productivity growth in the economy, such that a diminished size of the tradable sector would lower overall productivity growth of the economy permanently, thereby lowering long-term growth prospects.

Effects stemming from the second channel, often in combination with the third, are commonly referred to as Dutch Disease effects. Even though the model used in this paper is capable of shedding light on all three channels, this paper is going to focus mostly on the second, in particular on the link between fiscal and monetary policy choices and their impact on the tradable and non-tradable sectors via the real exchange rate. Issues related to the first channel, in particular how public investment can further economic development in natural resource-rich countries, have been explored in great detail in Berg et al. (2012b) employing an extended version of the model used here. The linkage between the tradable sector and overall economic development (the third channel) will be taken up in future work.

The outline of the task implies that we require a modeling framework that is sufficiently detailed in its presentation of the fiscal and monetary policy sectors to reflect the options currently considered by the government and Bank of PNG, plus it needs to have at least a tradable, non-tradable, and natural resource sector. The model we use in this paper has its roots in a modeling framework that was initially developed for researching the macroeconomic implications of scaling up aid inflows; specifically, it was employed as part of a project initiated by the United Nations Millennium Development Goals (MDG) Africa Steering Group to investigate for 10 countries how their national development plans would be impacted by scaled up development aid to Africa. ${ }^{4}$ Making use of the similarities between the macroeconomic impacts of aid and natural resource inflows, the model framework was subsequently expanded to include a natural resource sector and augmented with features necessary for investigating Dutch Disease effects and the efficacy of public investment. ${ }^{5}$ As noted above, a version of this model has been used previously to explore the role of public investment for natural resource-rich countries. Here, it will be employed to look into the macroeconomic transmission mechanism of fiscal spending of natural resource revenue inflows, with a focus on the real exchange rate and the impact on tradable and non-tradable

\footnotetext{
${ }^{4}$ See Berg et al. (2010) and Berg et al. (2012a).

${ }^{5}$ See Berg et al. (2012b).
} 
sectors, while taking into account different monetary policy options. This analysis of the transmission mechanism is used, first, to draw lessons for the conduct of fiscal policy and second, to clarify the role of monetary policy for macroeconomic stabilization.

To briefly summarize the model used here, besides the above-mentioned non-resource tradable sector, non-tradable sector and natural resource sector, it consists of households, firms, government and a central bank. Households comprise of savers and hand-to-mouth consumers. They make decisions regarding consumption and leisure. Producers operate in non-resource tradable and non-tradable goods sectors. They make decisions regarding labor and capital inputs to production. The natural resource sector has a simpler specification, with the production profile depending on exogenous foreign investment. The government collects revenues through tax receipts and dividends, which can be either spent or deposited. If it spends, it can either consume or invest. It if deposits, it can do so either at the central bank or in a sovereign wealth fund held offshore. The central bank can decide how much of the foreign exchange inflows to accumulate as reserves, which will influence the exchange rate, and whether to sell or buy government securities, thereby influencing the interest rate and money growth. Regarding the latter, the central bank can be modeled either as targeting an interest rate or money growth rate. These features, including the operation of an offshore sovereign wealth fund, match PNG's circumstances closely.

We will frame our discussion through a variety of policy scenarios. As such, this paper is designed to be policy-oriented, rather than a purely technical exposition. It is geared to the specific experiences and challenges facing PNG or countries with a similar economic profile, and it thus aimed to help policy-makers in such environments tackle the challenges facing them.

The simulations are primarily organized around the fiscal policy options that become available during a natural resource boom; essentially, the government needs to decide how much of the natural resource revenue inflows are to be spent or saved, and if resources are to be spent, on what and when? Indeed, we will see that the government's spending profile is the key determinant of the macroeconomic fluctuations following a resource boom. Each scenario was chosen for two reasons. Firstly, they represent a plausible and realistic combination of policy responses to a natural resource boom. Secondly, they shed light on the key aspects of the transmission mechanism that governs the manner in which the effects of the resource inflows filter through the economy. Based on the outline of policy issues above, we will look at the following questions:

- Should the government spend or save the revenue inflows?

- If it spends the inflows, what should it spend it on? Tradables or non-tradables?

- If it spends the inflows, when should it spend? Now or later? Do the existence of spending bottlenecks affect this decision?

- If it saves, what is the best way of saving? 
- Should the central bank accumulate reserves or not? Concurrently, if they do, should they sterilize these reserves?

These questions will form the basis for the scenarios later in the paper. Previewing the results, the central findings of the scenario simulations are as follows:

- Fiscal spending on non-tradables is what drives the macroeconomic effects.

- Front-loading of expenditures can lead to macroeconomic volatility, especially if the share of spending on non-tradables is high and there are bottlenecks in the economy.

- Monetary policy cannot undo the effect of counter-productive fiscal policy without cost.

- Saving through reserve accumulation will crowd-out private sector investment.

- Saving in an investment fund can considerably mitigate the adverse macroeconomic effects (at the cost of lower initial development gains as part of the revenue inflows are saved and not invested into the economy).

The paper proceeds as follows. Chapter II provides the model description in full. Chapter III discusses the calibration for PNG, giving details of the sources and rationale employed in the process. Chapter IV discusses a set of policy scenarios, centered on the question of whether the government should spend or save the resource revenues, that best match the requirements outlined above, simulating them using the model description and calibration for PNG. ${ }^{6}$ Chapter V concludes.

\section{The Model SetuP}

The model is a small open, New Keynesian economy with a natural resource sector. There are two types of consumers, a standard type that performs orthodox dynamic optimization, and a cash-constrained type that do not save, both of which make decisions over their labor and consumption spaces. We will call these types savers and hand-to-mouth consumers respectively. Firms are of one type, and make decisions regarding pricing, hiring and investment. There are three sectors, namely the (non-resource) tradable, non-tradable, and natural resource (mining) sectors. The last is crudely modeled, with the production profile and prices being essentially exogenously set. The non-tradable sector is modeled as exhibiting monopolistic competition whereas the tradable sector is perfectly competitive.

\footnotetext{
${ }^{6}$ The model was simulated and solved using the Dynare package. See http://www.cepremap.cnrs.fr/dynare.
} 
The central bank can engage in both reserve management and debt issuance. Reserve management is a function of an exchange rate targeting regime, that is, the bank can intervene in the forex market to maintain a certain exchange rate objective. Open market operations can be used to meet either a money supply or an interest rate target, as well as to sterilize a buildup of foreign exchange reserves.

The fiscal authority collects revenues through tax receipts and dividend payments. It can either spend or deposit its revenues. If it spends, it can either consume or invest, within either the tradable or non-tradable sectors. If it saves, it can either deposit its earnings at the central bank, or place them in an offshore sovereign wealth fund, which accrues interest at an exogenously determined rate.

The model assumes deterministic growth by labor-augmenting technology, and that all level variables grow at the same rate $n$ in the steady state. The description below is in terms of the de-trended model, which yields a stationary equilibrium.

\section{A. Households}

The economy is populated by two types of households: a fraction $f$ is savers, and $1-f$ is the hand-to-mouth. Both type of households are utility maximizers but savers have access to financial and capital markets, whereas the only asset that the hand-to-mouth household can hold is money. This distinction between the two types of households is meant to capture that in most economies, there are households that are too poor to build up significant savings and have to live from hand-to-mouth. Their poverty and lack of access to financial markets severely constrain their ability to respond to fluctuations in income, with the result that they are much less able to smooth their consumption by saving or dis-saving in response to income shocks, which makes their consumption profile much more volatile than that of savers. ${ }^{7}$ Modeling these households as a separate group is especially relevant for developing countries where a relatively large share of households is too poor or for other reasons does not have access to financial and asset markets. A superscript $a$ denotes a variable associated with savers and $h$ with the hand-to-mouth.

A representative saver chooses consumption $c_{t}^{a}$, the real money balance $m_{t}^{a}$, and labor $l_{t}^{a}$ to maximize the expected utility,

$$
E_{t} \sum_{t=0}^{\infty} \beta^{t}\left[u^{a}\left(c_{t}^{a}, m_{t}^{a}\right)-\frac{\kappa^{a}}{1+\psi^{a}}\left(l_{t}^{a}\right)^{1+\psi^{a}}\right],
$$

\footnotetext{
${ }^{7}$ The myopic behavior of the hand-to-mouth was initially introduced to capture the excessive consumption volatility in data as in Campbell and Mankiw (1989) and to capture the demand side effects of fiscal policy as in Mankiw (2000). The hand-to-mouth households are sometimes called non-savers, liquidity-constrained or rule-of-thumb consumers.
} 
subject to the budget constraint

$$
\begin{aligned}
\left(1+\tau_{t}^{c}\right) c_{t}^{a}+ & m_{t}^{a}+b_{t}^{a}+s_{t} b_{t}^{* a}+\frac{v}{2} s_{t}\left(b_{t}^{* a}-b^{* a}\right)^{2}= \\
& \left(1-\tau_{t}^{l}\right) w_{t} l_{t}^{a}+\frac{m_{t-1}^{a}}{n \pi_{t}}+\frac{i_{t-1} b_{t-1}^{a}}{n \pi_{t}}+s_{t} i^{*} \frac{b_{t-1}^{* a}}{n \pi^{*}}+\Omega_{t}^{T}+\Omega_{t}^{N}+s_{t} r m^{*}+z_{t} .
\end{aligned}
$$

The utility function takes the form

$$
u^{a}\left(c_{t}^{a}, m_{t}^{a}\right)=\frac{1}{1-\sigma}\left\{\left[\vartheta^{a}\left(c_{t}^{a}\right)^{\frac{\eta-1}{\eta}}+\left(1-\vartheta^{a}\right)\left(m_{t}^{a}\right)^{\frac{\eta-1}{\eta}}\right]^{\frac{\eta}{\eta-1}}\right\}^{1-\sigma} .
$$

$\sigma$ and $\psi^{a}$ are the inverses of the elasticity of intertemporal substitution for consumption and of the Frisch elasticity of labor supply. $\kappa^{a}$ is the preference weight on leisure. $\eta$ is the elasticity of intratemporal substitution between consumption and the real money balance. $\tau_{t}^{c}$ and $\tau_{t}^{l}$ are the consumption and labor tax rates, and $z_{t}$ is government transfers. We assume savers are the sole owners of firms in the non-traded and traded good sectors, and $\Omega_{t}^{T}$ and $\Omega_{t}^{N}$ are the after-tax profits from each sector (to be defined later).

The composite consumption $c_{t}^{a}$ consists of non-traded good $\left(c_{t}^{a N}\right)$ and traded $\operatorname{good}\left(c_{t}^{a T}\right)$, combined into a CES basket

$$
c_{t}^{a}=\left[\varphi^{\frac{1}{\chi}}\left(c_{t}^{a N}\right)^{\frac{\chi-1}{\chi}}+(1-\varphi)^{\frac{1}{\chi}}\left(c_{t}^{a T}\right)^{\frac{\chi-1}{\chi}}\right]^{\frac{\chi}{\chi-1}},
$$

where $\chi$ denotes the intratemporal elasticity of substitution, and $\varphi$ indicates the degree of consumption home bias. The non-traded goods are produced by a continuum of monopolistically competitive firms, indexed by $i \in[0,1]$. Aggregating all non-traded consumption varieties yields

$$
c_{t}^{a N}=\left[\int_{0}^{1}\left(c_{i t}^{a N}\right)^{\frac{\theta-1}{\theta}} d i\right]^{\frac{\theta}{\theta-1}}
$$

where $\theta$ is the elasticity of substitution between various pairs of non-traded goods.

The CES basket implies that the consumption price index for a unit of composite consumption is

$$
P_{t}=\left[\varphi\left(P_{t}^{N}\right)^{1-\chi}+(1-\varphi)\left(P_{t}^{T}\right)^{1-\chi}\right]^{\frac{1}{1-\chi}}
$$

where $P_{t}^{N}$ and $P_{t}^{T}$ are the nominal prices for non-traded and traded goods. The relative price of non-traded goods to the CPI is

$$
p_{t}^{N} \equiv \frac{P_{t}^{N}}{P_{t}} \text {. }
$$

We assume that the law of one price holds for the traded good so $P_{t}^{T}=S_{t} P^{*}$, where $S_{t}$ is the nominal exchange rate in units of domestic currency per dollar, and $P^{*}$ is the foreign CPI, 
assumed to be constant over time. The relative price of the traded good to the CPI is

$$
s_{t} \equiv \frac{S_{t} P^{*}}{P_{t}} .
$$

$s_{t}$ is also the CPI-based real exchange rate.

In addition to consumption, savers allocate their disposable income to various forms of assets. They hold a real money balance $m_{t}$, domestic government bonds $b_{t}^{a}$, and foreign assets $b_{t}^{* a}$. A unit of government bonds pays $\frac{i_{t} b_{t}^{a}}{n \pi_{t+1}}$ units of composite consumption at $t+1$, and a unit of foreign assets pays $\frac{i^{*} b_{t}^{* a}}{n \pi^{*}}$ units of foreign goods at $t+1$, where the foreign CPI inflation $\left(\pi^{*}\right)$ and the foreign nominal interest interest rate $\left(i^{*}\right)$ are assumed to be constant. Following Schmitt-Grohe and Uribe (2003), acquiring foreign assets is subject to a portfolio adjustment cost, $\frac{v}{2} s_{t}\left(b_{t}^{* a}-b^{* a}\right)^{2}$, where $b^{* a}$ denotes its steady-state value. The parameter $v$ governs the degree of capital account openness. A larger $v$ implies a more limited international capital mobility, as in developing countries.

Savers supply labor to the non-traded and traded good sectors. The elasticity of substitution between sectors is $\rho>0$, which affects the labor mobility between the two sectors. The total labor supplied by savers is

$$
l_{t}^{a}=\left[\delta^{-\frac{1}{\varrho}}\left(l_{t}^{a N}\right)^{\frac{1+\rho}{\varrho}}+(1-\delta)^{-\frac{1}{\varrho}}\left(l_{t}^{a T}\right)^{\frac{1+\rho}{\varrho}}\right]^{\frac{\rho}{1+\varrho}},
$$

where $\delta$ is the steady-state share of labor in the non-traded good sector. The real wage index is

$$
w_{t}=\left[\delta\left(w_{t}^{N}\right)^{1+\varrho}+(1-\delta)\left(w_{t}^{T}\right)^{1+\varrho}\right]^{\frac{1}{1+\varrho}} .
$$

The hand-to-mouth households have the same utility functional form as savers in (1) and (3), which allow for a different Frisch elasticity of labor supply $\frac{1}{\psi^{h}}$. To capture the short planning horizon in their economic decisions, the hand-to-mouth solve an intratemporal optimization problem, subject to the budget constraint

$$
\left(1+\tau_{t}^{c}\right) c_{t}^{h}+m_{t}^{h}=\left(1-\tau_{t}^{l}\right) w_{t} l_{t}^{h}+\frac{m_{t-1}^{h}}{n \pi_{t}}+s_{t} r m^{*}+z_{t} .
$$

Total labor supplied, $l_{t}^{h}$, is aggregated the same way as (9).

\section{B. Firms}

The economy has three production sectors: a non-traded good sector (denoted by a superscript $N$ ), a traded good sector excluding natural resources (by $T$ ), and a natural resource sector (by $O$, say for oil). As the vast majority of resource output is exported in 
Papua New Guinea, resource output in the model is solely for exports. Also, as resource production is capital intensive, labor is not used in natural resource production for simplicity.

\section{Non-traded Good Sector}

In the non-traded good sector, monopolistically competitive firm $i$ produces according to the technology

$$
y_{i t}^{N}=z^{N}\left(k_{i t-1}^{N}\right)^{1-\alpha^{N}}\left(l_{i t}^{N}\right)^{\alpha^{N}}\left(K_{t-1}^{G}\right)^{\alpha^{G}},
$$

where $K_{t}^{G}$ is public capital and $\alpha^{G}$ is the output elasticity with respect to public capital. Following the modeling convention of public capital in most of the neoclassical literature (e.g., Baxter and King (1993) and Kamps (2004)), we assume a constant return to scale with respect to the private production inputs and an increasing return to scale with respect to public capital.

Private capital evolves by the law of motion

$$
n k_{i t}^{N}=\left(1-\delta^{N}\right) k_{i t-1}^{N}+\left[1-\frac{\kappa^{N}}{2}\left(\frac{i_{i t}^{N}}{i_{i t-1}^{N}}-1\right)^{2}\right] i_{i t}^{N},
$$

where $\kappa^{N} \leq 0$ is the investment adjustment cost parameter.

A non-traded firm maximizes its net present-value profit weighted by savers' (firm owners') utility,

$$
\begin{aligned}
& E_{t} \sum_{t=0}^{\infty} \beta^{t} \lambda_{t}^{a}\left(1-\tau_{t}^{k}\right) \times \\
& \underbrace{\left\{(1-\iota)\left[p_{i t}^{N} y_{i t}^{N}-\frac{\varsigma}{2}\left(\frac{\pi_{i t}^{N}}{\pi_{i t-1}^{N}}-1\right)^{2} p_{t}^{N} y_{t}^{N}\right]-w_{t}^{N} l_{i t}^{N}-i_{i t}^{N}+\iota p_{t}^{N} Y_{t}^{N}\left[1-\frac{\varsigma}{2}\left(\frac{\pi_{t}^{N}}{\pi_{t-1}^{N}}-1\right)^{2}\right]\right\}}_{\equiv \tilde{\Omega}_{i t}^{N} \text {, prof it of firm } i},
\end{aligned}
$$

where $\lambda_{t}^{a}$ is the savers' marginal utility on consumption, $\pi_{t}^{N} \equiv \frac{P_{t}^{N}}{P_{t-1}^{N}}=\frac{p_{t}^{N}}{p_{t-1}^{N}} \pi_{t}$ is the inflation rate for non-traded goods, and $Y_{t}^{N}$ is the aggregate output of the non-traded sector. $\tau_{t}^{k}$ is the effective tax rate on corporate profits. ${ }^{8} \iota$ captures the distorting factors in developing countries that discourage firms from investing and hiring to achieve a higher level of production. Implicitly, $\iota$ acts like a distorting tax on firms but the revenues do not appear in

\footnotetext{
${ }^{8}$ Here we assume full expensing for investment costs when computing corporate profit taxes. In reality, firms are usually not allowed to fully expense investment costs within the period when investment is made.
} 
the government budget constraints. For simplicity, these revenues are rebated back to the firms within a sector in lump-sum fashion. The after-tax profit of the non-traded sector is

$$
\Omega_{t}^{N}=\left(1-\tau_{t}^{k}\right) \int_{0}^{1} \tilde{\Omega}_{i t}^{N} d i
$$

The (non-resource) traded sector is perfectly competitive and produced by the technology

$$
y_{i t}^{T}=z_{t}^{T}\left(k_{i t-1}^{T}\right)^{1-\alpha^{T}}\left(l_{i t}^{T}\right)^{\alpha^{T}}\left(K_{t-1}^{G}\right)^{\alpha_{G}} .
$$

The productivity $z_{t}^{T}$ is subject to learning-by-doing externalities, depending on the traded output of last period:

$$
\ln z_{t}^{T}=\rho_{z T} \ln z_{t-1}^{T}+d \ln y_{t-1}^{T} .
$$

This specification makes productivity growth a function of the size of the tradable sector; specifically, this implies that a shrinkage of the tradable sector due to a real appreciation caused by natural resource inflows will lower productivity growth in the tradable sector and thereby depress overall growth prospects of the economy. This is the "third channel" referenced in the introduction of how natural resource wealth can adversely affect economic development - a key element in the transmission mechanism leading to the "natural resource curse." However, as noted in the introduction, this channel will be explored in future work; in this paper, the learning-by-doing parameter will be set to a relatively small value, which means Dutch Disease effects in the form of a real appreciation and shrinkage of the tradable sector will not lead to a large deterioration in overall economic growth prospects.

The law of motion for capital is

$$
n k_{i t}^{T}=\left(1-\delta^{T}\right) k_{i t-1}^{T}+\left[1-\frac{\kappa^{T}}{2}\left(\frac{i_{i t}^{T}}{i_{i t-1}^{T}}-1\right)^{2}\right] i_{i t}^{T} .
$$

Like the non-traded good sector, $\kappa^{T}$ is the investment adjustment cost for the traded good sector. Each firm chooses labor, investment, and capital to maximize its weighted preset-value profits,

$$
E_{t} \sum_{t=0}^{\infty} \beta^{t} \lambda_{t}^{a}\left(1-\tau_{t}^{k}\right) \underbrace{\left[(1-\iota) s_{t} y_{i t}^{T}-w_{t}^{T} l_{i t}^{T}-i_{i t}^{T}+\iota s_{t} Y_{t}^{T}\right]}_{\equiv \tilde{\Omega}_{i t}^{T}, \text { profit of traded firm } i},
$$

where $Y_{t}^{T}$ is the aggregate output of the traded-good sector. The after-tax profit for the traded sector is

$$
\Omega_{t}^{T}=\left(1-\tau_{t}^{k}\right) \int_{0}^{1} \tilde{\Omega}_{i t}^{T} d i
$$

The model assume an exogenous process for the world commodity price, $P_{t}^{O *}$. Its relative 
price to the foreign CPI is $p_{t}^{O *} \equiv \frac{P_{t}^{O *}}{P^{*}}$, and the relative price to the domestic CPI is $s_{t} p_{t}^{O *}$. Denote a variable in percentage deviations from its steady state by a hat. The natural resource price follows an $\mathrm{AR}(1)$ process

$$
\hat{p}_{t}^{O *}=\rho_{p o} \hat{p}_{t-1}^{O *}+\varepsilon_{t}^{p o},
$$

where $\varepsilon_{t}^{p o} \sim$ i.i.d.N $\left(0, \sigma_{p o}^{2}\right)$ is the resource price shock.

The model abstracts from natural resource investment decisions; it assumes that resource investment is financed by foreign direct investment (FDI). The FDI in the resource sector $\left(i_{t}^{f *}\right.$, denominated by foreign currency) follows an AR(1) process

$$
\hat{i}_{t}^{f *}=\rho_{f} \hat{i}_{t-1}^{f *}+\varepsilon_{t}^{f},
$$

where $\varepsilon_{t}^{f} \sim$ i.i.d.N $\left(0, \sigma_{f}^{2}\right)$ is the FDI shock. Resource investment in the price of domestic consumption is

$$
I_{t}^{O}=s_{t} i_{t}^{f *}
$$

The capital in the resource sector evolves according to the law of motion,

$$
n K_{t}^{O}=\left(1-\delta^{O}\right) K_{t-1}^{O}+I_{t}^{O} .
$$

Resource output is produced with a CES technology, using capital and imported intermediate goods $X_{t}^{*}$

$$
Y_{t}^{O}=z_{t}^{O}\left[\left(\alpha^{O}\right)^{\frac{1}{\xi}}\left(K_{t-1}^{O}\right)^{\frac{\xi-1}{\xi}}+\left(1-\alpha^{O}\right)^{\frac{1}{\xi}}\left(s_{t} X_{t}^{*}\right)^{\frac{\xi-1}{\xi}}\right]^{\frac{\xi}{\xi-1}},
$$

where $\xi$ is the elasticity of substitution between intermediate goods and capital. $\xi^{O}$ approaching 0 implies little substitutability between the two production factors. $z_{t}^{O}$ is the total factor productivity for the resource sector, following an AR(1) process

$$
\hat{z}_{t}^{O}=\rho_{z o} \hat{z}_{t-1}^{O}+\varepsilon_{t}^{z o}
$$

and where $\varepsilon_{t}^{z o} \sim$ i.i.d.N $\left(0, \sigma_{z o}^{2}\right)$ is the resource productivity shock.

The government levies royalties based on production quantity with a rate $\tau_{t}^{o}$. The resource sector's net profit in dollars is

$$
\Omega_{t}^{O *}=\left(1-\tau_{t}^{o}\right) p_{t}^{O *} Y_{t}^{O}-s_{t} X_{t}^{*} .
$$

In addition to taxes, the government also receives a share of dividends of resource profits and interest income from the SWF $\left(F_{t}^{*}\right)$. Let $\iota^{d i v}$ be the dividend share that the government 
receives. Total resource revenues collected each period are

$$
T_{t}^{O}=s_{t}[\underbrace{\tau^{o} p_{t}^{O *} y_{t}^{O}+\iota^{d i v} \Omega_{t}^{O *}+\frac{\left(i^{*}-1\right) F_{t-1}^{*}}{n \pi^{*}}}_{T_{t}^{O *}}],
$$

where $\frac{\left(i^{*}-1\right) F_{t-1}^{*}}{n \pi^{*}}$ is the interest earning on the sovereign wealth fund. Finally, the nominal GDP in the price of domestic consumption is

$$
Y_{t}=p_{t}^{N} Y_{t}^{N}+s_{t} Y_{t}^{T}+s_{t} p_{t}^{O *} Y_{t}^{O} .
$$

To calculate real GDP, each sector's output is evaluated at its steady-state prices relative to the CPI.

\section{Fiscal Policy}

The government's flow budget constraint each period is

$T_{t}+B_{t}-\left(D_{t}^{G}-\frac{D_{t-1}^{G}}{n \pi_{t}}\right)+s_{t} A^{*}+s_{t}\left(\frac{F_{t-1}^{*}}{n \pi^{*}}\right)=p_{t}^{g} G_{t}+Z_{t}+\left(i_{t-1}-1\right) \frac{B_{t}^{c}}{n \pi_{t}}+\frac{B_{t-1}}{n \pi_{t}}+s_{t} F_{t}^{*}$,

where $B_{t}$ is total government debt outstanding, $B_{t}^{c}$ is government debt held by consumers, $D_{t}^{G}$ is government deposits at the central bank, $A^{*}$ is foreign aid, $G_{t}$ is government purchases, and $Z_{t}$ is transfers to households. Total government receipts $T_{t}$ include taxes on labor income, corporate profits, and consumption, royalties and dividends from resource production, and the interest earning from the sovereign wealth fund:

$$
T_{t}=\tau_{t}^{c} C_{t}+\tau_{t}^{l} w_{t} L_{t}+\tau_{t}^{k}\left(\Omega_{t}^{N}+\Omega_{t}^{T}\right)+T_{t}^{O} .
$$

Since one objective of the PNG authorities is to scale up its public investment using resource revenues, we account for common problems associated with investing in developing countries, including investment inefficiency and absorptive capacity constraints. To capture the typical long process in building infrastructure, a time-to-build process is assumed for public capital, following Kydland and Prescott (1982) and Leeper et al. (2010). Let $g_{0}, g_{1}, \ldots, g_{k-1}$ be the spending rate of public investment budget authorized, $X_{t}^{G I}$. Then, total expenditure of public investment executed at $t$ is

$$
G_{t}^{I}=\sum_{j=0}^{k-1} g_{j} X_{t-j}^{G I}, \quad \sum_{j=0}^{k-1} g_{j}=1 .
$$


To model absorptive capacity constraints often observed in developing countries, we distinguish between the expenditure of public investment $\left(G_{t}^{I}\right)$ and effective public investment $\left(\tilde{G}_{t}^{I}\right)$. The difference between the two is the costs due to absorptive capacity constraints. Specifically,

$$
\log \frac{\tilde{G}_{t}^{I}}{\tilde{G}^{I}}=b \times \log \frac{G_{t-1}^{I}}{G^{I}}, \quad 0 \leq b \leq 1
$$

where $b$ governs the severity of absorptive capacity constraints. When $G_{t}^{I}<G^{I}$, meaning the expenditure on public investment is above its steady-state level, $b>0$; otherwise, $b=0 .{ }^{9}$

To reflect lower institutional quality relative to advanced economies in developing countries, the model builds in investment inefficiency $(\epsilon<1)$, consistent with the observation in Pritchett (2000). The law of motion of public capital $K_{t}^{G}$ is

$$
K_{t}^{G}=\left(1-\delta^{G}\right) K_{t-1}^{G}+\epsilon \tilde{G}_{t}^{I}
$$

where $\delta^{G}$ is the depreciation rate of public capital.

In addition to public investment, total government purchases $G_{t}$ includes government consumption $\left(G_{t}^{C}\right)$. Like private consumption, total government purchases is a CES basket, consisting of traded and non-traded goods,

$$
G_{t}=\left[\nu^{\frac{1}{\chi}}\left(G_{t}^{N}\right)^{\frac{\chi-1}{\chi}}+(1-\nu)^{\frac{1}{\chi}}\left(G_{t}^{T}\right)^{\frac{\chi-1}{\chi}}\right]^{\frac{\chi}{\chi-1}}
$$

where $\nu$ denotes the degree of home bias in government purchases. The relative price of government purchase to $\mathrm{CPI}$ is

$$
p_{t}^{G}=\left[\nu\left(p_{t}^{N}\right)^{(1-\chi)}+(1-\nu)\left(s_{t}\right)^{1-\chi}\right]^{\frac{1}{1-\chi}} .
$$

The government adopts simple rules in terms of constant shares in allocating natural resource revenues. A natural resource windfall, $T_{t}^{O}-T^{O}$, is defined as the additional resource revenue received beyond the steady-state level $\left(T^{O}\right)$. Fiscal decisions can be characterized by a two-stage process. In the first stage, the government decides on the share of $T_{t}^{O}-T^{O}$ to be saves in a SWF $\left(F_{t}^{*}\right)$, denoted by $\phi^{f}$. For a given share of a windfall saved $\left(\phi^{f}\right)$, the law of motion of the SWF is

$$
F_{t}^{*}=\left(1-\frac{1}{n \pi^{*}}\right) F^{*}+\frac{1}{n \pi^{*}} F_{t-1}^{*}+\frac{1}{s_{t}}\left[\phi^{f}\left(T_{t}^{O}-T^{O}\right)\right],
$$

\footnotetext{
${ }^{9}$ The linear specification of (33) implies a 1-percent increase in public investment expenditures above the steady-state level leads to $b$-percent increase in effective public investment. The costs of absorptive capacity constraints in reality, however, are likely to be non-linear, depending on the level of investment. Berg et al. (2012b) specifies a convex function to capture rising absorptive capacity constraint costs along with the public investment level.
} 
where the interest earning at $t$ from the SWF at $t-1\left(\frac{\left(i^{*}-1\right) F_{t-1}^{*}}{n \pi^{*}}\right)$ is included in $T_{t}^{O}$; see (28).

In the second stage, the government decides on how to spend the unsaved windfall among transfers, government consumption, and public investment. ${ }^{10}$ Government spending rules are specified as

$$
G_{t}^{C}=G^{C}+\frac{1}{p_{t}^{G}}\left(1-\phi^{f}\right) \phi^{g c}\left(T_{t}^{O}-T^{O}\right)
$$

and

$$
G_{t}^{I}=G^{I}+\frac{1}{p_{t}^{G}}\left(1-\phi^{f}\right) \phi^{g i}\left(T_{t}^{O}-T^{O}\right) .
$$

All other fiscal variables, including tax rates, transfers, and debt are held at the steady-state levels.

\section{E. Reserve and Monetary Policy}

Denote the government debt held by the central bank with $B_{t}^{c b}$ and the foreign reserve with $R_{t}^{*}$. The central bank's balance sheet is

$$
m_{t}-\frac{m_{t-1}}{n \pi_{t}}+D_{t}^{G}-\frac{D_{t-1}^{G}}{n \pi_{t}}=B_{t}^{c b}-\frac{B_{t-1}^{c b}}{n \pi_{t}}+s_{t}\left(R_{t}^{*}-\frac{R_{t-1}^{*}}{n \pi^{*}}\right) .
$$

The reserve policy follows the process

$$
\frac{R_{t}^{*}}{R^{*}}=\left(\frac{R_{t-1}^{*}}{R^{*}}\right)^{\rho_{R}}\left(\frac{T_{t}^{O *}}{T^{O *}}\right)^{\omega_{o}}\left(\frac{\pi_{t}^{S}}{\pi^{S}}\right)^{-\omega_{s}},
$$

where $\omega_{o}$ indicates the share of oil windfall the flexibility of the nominal exchange, and $\pi_{t}^{S}=\frac{S_{t}}{S_{t-1}}$ is the growth rate of the nominal exchange, assumed to be 1 in the steady state. $\omega=0$ indicates a flexible exchange rate.

To conduct monetary policy, the central bank adopts a Taylor-type rule, responding to the lagged nominal interest rate and changes in output, inflation, and the money growth rate:

$$
\frac{i_{t}}{i}=\left(\frac{i_{t-1}}{i}\right)^{\rho_{i}}\left[\left(\frac{Y_{t}}{Y}\right)^{\phi_{y}}\left(\frac{\pi_{t}}{\pi}\right)^{\phi_{\pi}}\left(\frac{\mu_{t}}{\mu}\right)^{\phi_{\mu}}\right]^{\left(1-\rho_{i}\right)},
$$

where $\mu_{t}=\frac{n M_{t}}{M_{t-1}} \pi_{t}$ is the growth rate of nominal money balance.

\footnotetext{
${ }^{10}$ The government, of course, can also use a windfall to lower taxes or to pay down its debt. Given a large number of fiscal choices available by combining various options, we focus on relevant option of government consumption and public investment for PNG.
} 


\section{F. Aggregation and Some Identities}

Let $X_{t}$ denote the aggregate quantity of a variable. Then,

$$
X_{t}=f x_{t}^{a}+(1-f) x_{t}^{h}, \quad x \in\left\{c, c^{N}, c^{T}, m, l, r m^{*}, b^{*}, b^{c}\right\} .
$$

In addition, the total government bonds is

$$
B_{t}=B_{t}^{c}+B_{t}^{c b}
$$

The total demand for non-traded goods is

$$
D_{t}^{N}=\varphi\left[C_{t}^{N}+I_{t}^{N}+I_{t}^{T}+\frac{\varsigma}{2}\left(\frac{\pi_{i t}^{N}}{\pi_{i t-1}^{N}}-1\right)^{2} p_{t}^{N} y_{t}^{N}\right]+\nu\left(p_{t}^{G}\right)^{\chi} G_{t}
$$

Note that all oil investment uses traded goods only. The market clearing condition for the non-traded good is

$$
Y_{t}^{N}=\left(p_{t}^{N}\right)^{-\chi} D_{t}^{N}
$$

Current account deficits $\left(C A_{t}^{d}\right)$ of the model economy are

$$
\begin{aligned}
C A_{t}^{d}=\left[C_{t}+I_{t}+\right. & \left.p_{t}^{G} G_{t}+\frac{\zeta}{2}\left(\frac{\pi_{t}^{N}}{\pi_{t-1}^{N}}-1\right)^{2} p_{t}^{N} y_{t}^{N}\right] \\
& \quad-p_{t}^{N} y_{t}^{N}-s_{t} y_{t}^{T}-s_{t} p^{O *} y_{t}^{O}-s_{t}\left(i^{*}-1\right) \frac{B_{t-1}^{*}+F_{t-1}^{*}}{n \pi^{*}}-s_{t} r m^{*},
\end{aligned}
$$

where $I_{t}=I_{t}^{N}+I_{t}^{T}+I_{t}^{O}$. The balance of payment condition is

$$
\begin{aligned}
C A_{t}^{d}= & s_{t}\left[A^{*}-\frac{v}{2}\left(B_{t}^{*}-B^{*}\right)^{2}\right] \\
& +s_{t}\left\{\left[i_{t}^{f *}-\left(1-\iota^{d i v}\right) \Omega_{t}^{O *}\right]+\left(\frac{F_{t-1}^{*}+B_{t-1}^{*}+R_{t-1}^{*}}{n \pi^{*}}-F_{t}^{*}-B_{t}^{*}-R_{t}^{*}\right)\right\} .
\end{aligned}
$$

\section{Calibration}

We give a brief overview and description of the calibration of the model parameters to the PNG econonomy. As many of the parameter values are taken directly from Berg et al. (2010), we omit a detailed discussion of the calibration background and justification. We partition the parameters into three categories: technology, preference parameters and national accounts steady-state values. 
Regarding the technology parameters, the labor intensity of production is a key factor for the dynamic responses of the model. In the absence of an input-output table for PNG, the labor income share has been set to 0.7 , which is in line with standard values in the literature. The calibration for the elasticity of output with respect to public capital is based on regression results in Arslanalp et al. (2010), who find for non-OECD countries elasticities ranging from 0.1 at the 1 year horizon to 0.25 at the 10 year horizon. Here, the calibration uses an elasticity of 0.1 reflecting first that the intended forecast horizon of our model is approximately one to five years and second capacity constraints in PNG regarding planning and implementation of public investment argue for a choice of a lower-than-average elasticity. The learning-by-doing parameters that are meant to capture long-run Dutch Disease effects on economic growth have been set to a relatively low value, as mentioned before. A more detailed analysis of these effects will be taken up in future work. Finally, the capital account has been closed through high portfolio adjustment costs, reflecting an assessment by Bank of PNG staff that portfolio flows are not very sensitive to interest rate differentials.

Turning to the preference parameters, the relatively low home bias of 0.3 has been computed from national accounts data that show the share of the non-tradable sector in total output to be small, which in turn implies a low share of domestically-produced non-tradable goods in total consumption. The substitution elasticities have been taken from Berg et al. (2010) and Berg et al. (2012b); especially noteworthy is the Frisch elasticity for hand-to-mouth consumers that has been calibrated to minimize the labor supply response of these consumers to variations in their income, thereby preventing them from reducing their labor supply sharply whenever their income rises due to higher wages or transfers, which would have been unrealistic. ${ }^{11}$ The money demand elasticity has likewise been calibrated to prevent interest rate fluctuations to become unrealistically large.

Finally, the steady state values for the national account variables are all calculated using the GDP data as provided by the National Statistics Office of PNG until 2006. Absence of published GDP data since 2006 necessitates the use of Ministry of Treasury official estimates thereafter. For 2011 data currently unavailable, the nominal growth rates from 2010 were applied. The steady state values have been computed as the average over 2000-06, presenting "normal" conditions prior to the commodity price boom in the second half of the 2000's.

\section{Policy Simulations}

Having set the model up for PNG, we are now in a position to be able to run a suite of policy simulations. The following scenarios were chosen to both simulate possible realistic policy responses to the resource inflows, as well as for their ability to demonstrate the pros and cons of certain policy choices. We center the discussion around one central question: should the government spend or save the resource revenues? Each option is analyzed further, with the

\footnotetext{
${ }^{11}$ See also the discussion in Berg et al. (2012b), pages 15 and 19.
} 
spending choice broken down into temporal and sectoral considerations, and the saving option broken down into reserve accumulation versus investment in a sovereign wealth fund.

\section{A. Spending}

In this section, we concentrate on scenarios in which the government spends the entirety of the revenues.

\section{The Baseline Scenario}

This scenario will act as a benchmark for all subsequent simulations. It is constructed to reflect both a policy mix that often prevails in the event of resource revenue inflows. We use the parameterization as outlined in the previous section. The government spends 90 percent of the inflows on consumption, and the remainder on investment. Of that which is consumed, 70 percent is spent on non-tradables $\left(\nu_{g}=0.7\right)$. This specification highlights the macroeconomic effects of government consumption; spending increases on public investment would likely have a lower share of spending on non-tradables and therefore a smaller macroeconomic impact, as will be shown in the first policy scenario, plus public investment raises overall GDP in the medium term by building up the public capital stock. Regarding the baseline specification for monetary policy, the central bank sells the entirety of its foreign exchange inflows on the forex market, and is interest-rate targeting.

The results for an oil price shock are presented in Figure 2. ${ }^{12}$ The increase in oil prices leads to a surge in oil revenues to the government. The macroeconomic impacts of the surge in oil revenue inflows is driven by government spending, which increases in line with the oil revenue inflows, given that we assume here that the government spends the entirety of revenue inflows. As a direct consequence of the government spending profile, demand for non-tradables increases. Since this sector is characterized by monopolistic competition, the demand shock translates in the short-run into increases to both prices and production in this sector. The latter requires increases in factors of production, which occurs through labor migration from the tradables sector as well as increased investment in non-tradables. ${ }^{13}$ Given the upward pressure on non-tradable prices resulting from the shift in demand from non-tradables to tradables, non-tradable prices increase relative to tradable prices, which implies that the real exchange rate appreciates. In the absence of interventionalist central bank policy, this appreciation does manifest. As a result, profitability in the domestic tradable sector declines, facilitating an outward migration of capital and labor.

\footnotetext{
${ }^{12}$ Only the key macroeconomic variables are shown here. The plots are annual impulse responses as measured as a percentage deviation from steady state.

${ }^{13}$ It should be noted that investment is a slower process than labor migration, and hence embodies a longer-term strategy for increasing production.
} 
The real appreciation causes a widening of the current account deficit, for two reasons. ${ }^{14}$ First, the real appreciation makes tradables relatively cheaper, causing overall demand for tradables, and hence import, to increase. Second, owing to the shrinking domestic tradable sector, a greater portion of that demand must be met through imports. Finally, owing to the persistence of the exchange rate appreciation, overall inflation falls, triggering a moderate loosening of monetary policy (a decrease in the real interest rate) in the short-run.

To summarize, the macroeconomic effects of resource inflows are driven largely by fiscal spending, in particular on non-tradables. More specifically, the macroeconomic effects occur as a result of the economy needing to restructure to meet the government demand for non-tradables.

Before turning to the policy simulations, it is useful to outline how we are going to judge whether a given policy setting improves macroeconomic outcomes relative to the baseline or not. One intuitive option would have been to focus on the output response, as measured by the real non-oil GDP response in our figures, with a higher medium-term output response pointing to a more preferable macroeconomic outcome. We do not follow this path because the medium-term output response depends mostly on the degree to which the government uses oil revenue inflows to increase public investment and to what degree the resulting public capital accumulation is sustainable. Given that this issue is discussed comprehensively in Berg et al. (2012b), we focus instead on the macroeconomic effects of government consumption, as noted above in the specification of the baseline scenario. Taking into account that the oil price shocks in our simulations are temporary and that using oil revenues mostly for consumption will not build up the public capital stock in any sustainable manner, in the medium term all our macroeconomic variables can be expected to revert to their baseline value, which corresponds to the zero line in our figures. Hence, measuring the medium-term response will tell us little about the relative desirability of the macroeconomic outcomes. Rather, the benchmark will be the degree of macroeconomic volatility generated by the different scenarios, with lower volatility being more desirable. We use the term macroeconomic volatility loosely and measure it informally by observing how much the macroeconomic variables fluctuate around their baseline values in our simulations, that is, in the graphical presentation of our simulation results, we focus on how large and frequent deviations of the depicted impulse response functions are from the zero line. ${ }^{15}$ Given that we do not claim that our model can generate reliable quantitative projections, this qualitative approach is sufficient for our purpose. Finally, before moving on it is worth asking why do we care about macroeconomic volatility? At a general level, macroeconomic stability is a widely accepted objective of fiscal and monetary policies, so aiming for low macroeconomic

\footnotetext{
${ }^{14}$ This is shown in the chart through the increase in absorption, which corresponds to a widening of the current account deficit.

${ }^{15}$ An alternative would have been to measure macroeconomic volatility more formally by computing the standard deviations of key variables such as real non-oil GDP or the real exchange rate, but this would have lengthened our paper without generating much additional information, given that the graphical results depict very clearly which scenarios are more volatile than others.
} 
volatility makes a natural benchmark. A related argument, which we discuss in more detail in the scenario with front-loaded spending, is that mobilizing production factors and reallocating them among sectors are not costless activity, which implies that temporarily ramping up non-tradable production is inherently wasteful, especially so if the production increase is short-lived. Hence, the economy is likely to be better off with gradual, sustained adjustment processes.

\section{Inter-sectoral Spending Profile}

The results of the baseline scenario suggest that macroeconomic volatility depends on the profile of government spending. This profile can vary both inter-temporally and inter-sectorally, that is, how fast the government spends the inflows, and in which sectors. The current simulation will vary the sectoral spending profile. In particular, the government will now devote 80 percent of spending on tradables $\left(\nu_{g}=0.2\right)$. The remainder of the assumptions are as per the baseline.

Figure 3 shows the results of the simulation. Now, the increase in non-tradable demand is much smaller, thus resulting in smaller increases in non-tradable prices and output and hence a smaller migration of labor and capital to this sector. Concurrently, the tradable sector retains a greater proportion of overall demand, experiencing a smaller price drop and hence retains its profitability. ${ }^{16}$

The current account widens as per the baseline, this time through direct government spending on imports. The overall inflationary pressure is identical to that in the baseline. This is because the smaller nominal appreciation — which constitutes a disinflationary pressure-is directly offset by the smaller increase in non-tradable prices.

This simulation proves that it is not the resource inflows per se that cause the macroeconomic volatility, but rather government spending on non-tradables. The key issue is that the supply of non-tradables is limited by domestic production whereas supply for tradables is unlimited, as demand which is not met domestically can be met through imports. Hence, spending on tradables has limited macroeconomic effects, whereas spending on non-tradables, through the limited supply response, generates large macroeconomic effects.

\section{Inter-temporal Spending Profile}

The previous scenario altered the inter-sectoral spending profile of the government. This simulation will vary the speed of spending and compare a scenario with front-loaded fiscal spending to an alternative scenario with a smooth spending profile. The most relevant

\footnotetext{
${ }^{16}$ Both measures of the real exchange rate - the nominal CPI-deflated and the non-tradable/tradable ration-demonstrate a smaller appreciation than in the baseline scenario.
} 
situation for a front-loaded fiscal spending scenario is the occurrence of a temporary oil price shock. In the previous simulations, the oil price shock was fairly persistent, which we need to modify here by shortening the period over which oil prices are elevated in order to make the oil price shock more temporary-more than 90 percent of the oil price shock dissipates now after three years, compared to approximately ten years under the previous specification-and reduce the size of the shock accordingly.

Beginning with the specification of the front-loaded fiscal spending scenario, in this scenario the government spends all of the oil revenues as they come in, which implies a large ramping up of expenditures as oil prices surge initially, followed by a fairly rapid reduction in spending as oil prices fall again. Apart from the modified path for oil prices, the settings for the front-loaded spending scenario are identical to those of the baseline.

The alternative scenario implements a smoother spending profile. The section on Sovereign Wealth Funds will consider a case where a temporary increase in oil revenue is transformed into a small but permanent increase in spending, which could be considered as the ultimate smoothing of the spending profile. In this section, we are going to consider an intermediate case where spending of the temporary rise in oil receipts is spread relatively evenly over five years. To implement this limited form of smoothing, it is necessary for the government to save parts of the temporary oil revenues that are not initially spent and draw on these savings when spending exceeds the level of oil revenue inflows; we implement this in the model simulation by transferring initial fiscal surpluses into the government deposit with the central bank, followed by a draw down in later years to finance budget deficits that arise when oil revenues have receded and spending is still elevated. We also modify the foreign exchange management by the central bank for the smoothing scenario: instead of selling all foreign exchange inflows, we assume that the central bank will sell an amount of foreign exchange that matches the amount of government spending financed out of the additional oil revenues. As a result, the buildup of government deposits in the early years when the government saves part of the temporary oil revenue inflows is matched with a corresponding buildup of foreign exchange reserves, which leaves the overall money supply broadly unchanged. Likewise, when the government draws down its government deposits to finance fiscal deficits, the stock of central bank foreign exchange reserves will fall as well. Hence, smoothing in this scenario applies both to fiscal spending and foreign exchange management, which has the effect of aligning economy-wide absorption (that is, the path of the non-oil current account deficit) with the path of the fiscal deficit. This is a key characteristic of the baseline scenario where fiscal spending and foreign exchange management are aligned as well through spending of all oil revenue inflows by the government and sale of all foreign exchange inflows by the government. Technically, the smoothing of foreign exchange sales is implemented by making the nominal exchange rate somewhat sticky.

The results for the two scenarios are shown in Figure 4. In essence, the evolution of the macroeconomy occurs through a more sustained, gradual process in the scenario with smooth spending compared to the front-loaded spending scenario. The contrast highlights the undesirable consequences of front-loading spending, which fall into two categories: 
1. Macroeconomic volatility. Strong macroeconomic pressures emerge during front-loaded spending, all of which subside as spending slows down, allowing variables to return to steady state. The result is significant macroeconomic volatility. For example, the real exchange rate appreciates by about 6.5 percent at its peak under the front-loaded spending scenario, whereas in the smooth spending alternative, the appreciation peaks at only about 2.5 percent. The same difference in volatility is visible for inflation, nominal interest rates, and output variables.

2. Costs. Front-loaded spending results in economic costs that cannot be captured in the model predictions. These stem from the massive reallocation of labor to the non-tradable sector when spending surges, and subsequent re-allocation to tradables once spending recedes. The model assumes frictionless labor migration. However, in reality, such movements will undoubtedly be accompanied by periods of unemployment, itself costly to both individuals and the broader economy, and possibly periods of low productivity in the non-tradable sector, as newly arriving workers require retraining to acquire the necessary skills. The model also assumes that the tradable sector merely "hibernates" during the spending spree. In reality, some firms in the tradable sector that are shuttered during the spending surge in the front-loaded spending scenario will be unable to restart their business when spending recedes, leading to permanent output losses.

In summary, front-loading spending should be avoided because of macroeconomic volatility and economic costs caused by these policies. ${ }^{17}$ The costs of front-loaded expenditures would be even more pronounced if there are bottlenecks to effective public spending. See Box 1 for further details.

\section{Box 1: Absorptive Capacity Costs}

We have seen how the inter-temporal spending profile of the government drives much of the macroeconomic volatility experienced by the economy. To further investigate the impact of this spending profile on overall growth, we introduce the presence of absorptive capacity costs to rapid spending. When front-loading spending, the government experiences bottlenecks to public financial management implementation; poorly chosen projects are poorly implemented. More precisely, as the volume of public spending increases, so too does the inefficiency of investment. Hence, with the bottleneck effect, ceteris paribus, public capital accumulation is lower, leading to reduced non-resource

\footnotetext{
${ }^{17}$ Of course, an alternative is to mitigate the macroeconomic effects of a front-loaded spending profile by aiming for a high import content of spending and raising public investment; provided the buildup of public capital is sustainable, the last will raise output permanently and thereby boost the supply response of the economy.
} 
growth. Conversely, if spending is gradual, such capacity costs are reduced, leading to more efficient public investment, increased growth and prevention of Dutch Disease effects. In order to capture such non-linear effects, the model is augmented using the following equation to describe absorptive capacity costs:

$$
\tilde{G}_{t}^{I}=\left[1-b\left(\frac{G_{t}^{I}}{G^{I}}\right)^{2}\right] G_{t}^{I}, \quad b \geq 0
$$

The greater the value of the parameter $b$, the smaller the ratio $\frac{\tilde{G}_{t}^{I}}{G_{t}^{I}}$, that is, the less effective is public investment. The Figure demonstrates these effects by comparing the results for a small value (solid line) to a large value of $b$ (dashed line). It needs to be emphasized that the simulation results are only illustrative, because the functional form and parameter values are chosen necessarily on an ad-hoc basis.
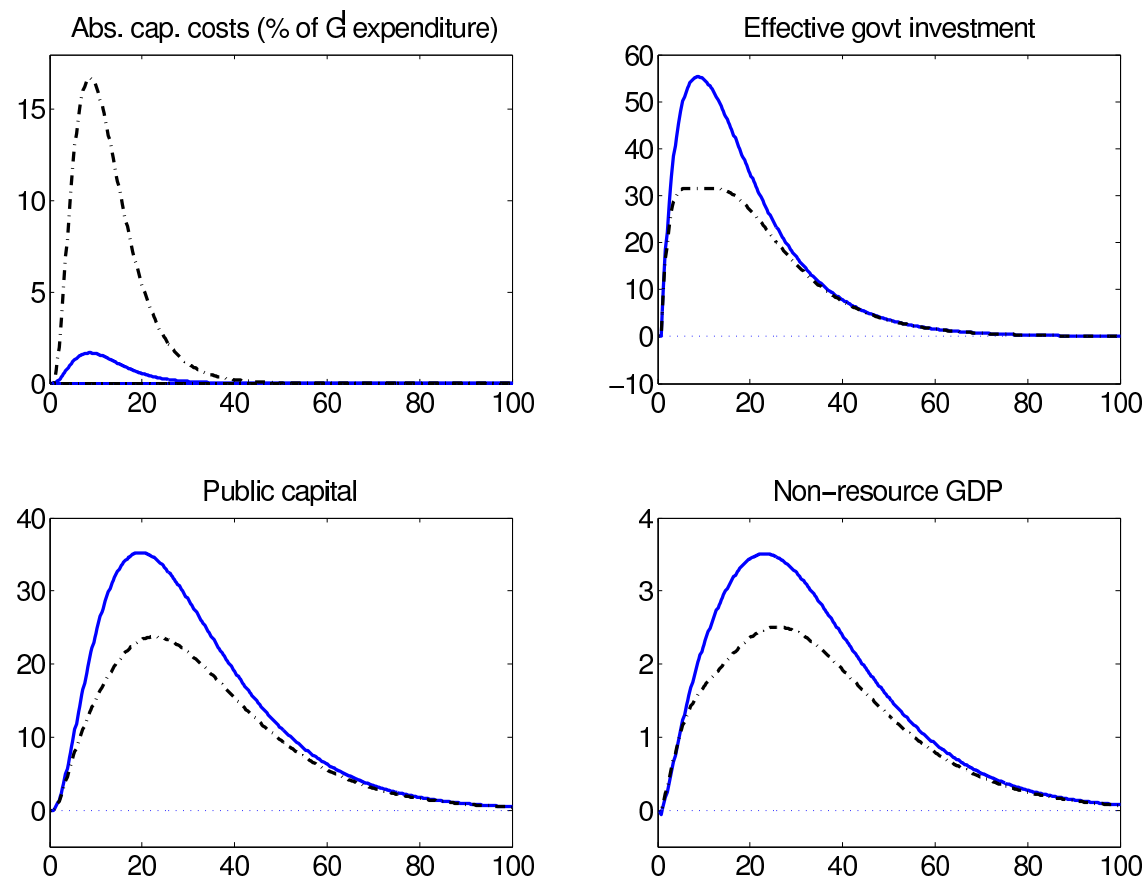

Figure 1. Absorptive Capacity Costs

\section{Monetary Policy}

We have seen how rapid government spending on non-tradables can result in Dutch disease effects in the form of a real appreciation and reduction in tradable sector output, which leads to the question "Can monetary policy be used to mitigate the effects of Dutch Disease?" So far, the simulations assumed that the central bank would sell all of the foreign exchange 
inflows stemming from the increase in oil revenues; this is a key factor for the nominal appreciation under the baseline and by extension for the real appreciation. Hence, if the central bank wants to prevent a real appreciation, a first step would be to start accumulating the foreign exchange inflows as reserves instead of selling them. However, this would result in a large expansion in money supply that would fuel inflation and lead to a real appreciation. Moreover, the inflationary pressures could become large enough to risk unhinging inflation expectations. Hence, this policy would have to be accompanied by a sterilization of the increase in money supply in order to contain inflation. That is, the monetary policy stance would need to be very tight. Both types of policies-reserve accumulation and sterilization-will be implemented in this alternative scenario.

The central bank now retains 70 percent of the foreign exchange it acquires through the resource inflows as foreign reserves $\left(\omega_{o}=0.7\right)$. In order to offset the effect of this accumulation on domestic money, they also issue public debt to sterilize the reserve accumulation. ${ }^{18}$ We adapt the interest rate targeting regime to be stricter in response to inflation $\left(\phi_{\pi}=5\right)$. This sharpens the contrast between the baseline and the current simulation, which is beneficial for the purposes of illustration. We revert to imposing a persistent oil price shock as under the original baseline specification.

Figure 5 shows the results of the simulation. The reserve accumulation policy is effective in mitigating the sizable nominal exchange rate appreciation seen in the baseline, which in turn keeps the real appreciation to a limit. As as result, the tradable sector remains largely competitive, with production dropping, but by far less than under the baseline. In this regard, monetary policy has been successful in protecting the tradable sector from a real appreciation and subsequent loss of competitiveness. Furthermore, from a fiscal perspective, reserve accumulation does not significantly affect the demand for non-tradables, and the economy still generates the necessary supply response to front-loaded spending. Hence, it would appear that this alternative Pareto dominates the previous alternatives.

However, it is instructive to compare how the demand for non-tradables is met in this scenario. In the baseline, non-tradable demand is met through factor migration which itself is facilitated through a real appreciation. In Scenario 2, it is met through direct government spending on imports. However, these avenues are both blocked in this setting, the first by the central banks reserve management, and the second because of the government's spending profile. Instead, the sterilization that accompanies the reserve accumulation constitutes a monetary tightening, that is, real interest rates increase dramatically. This causes a crowding-out of the private sector, that is, private sector demand falls, thereby freeing up supply capacity of the economy that can be used to meet expanding government demand. Thus, whilst the first two scenarios exhibit a change in the profile of private sector demand,

\footnotetext{
${ }^{18}$ It should be noted that full sterilization is also set in the baseline, but since there is no reserve accumulation, there is nothing to sterilize.
} 
this scenario yields a drop in overall private demand. ${ }^{19}$ Essentially, the process is identical to an orthodox debt financed fiscal expansion, since the central bank absorbs the foreign impact and issues public debt to the same amount, and as such, the ensuing crowding-out is inevitable. As a side effect of the reduction in private sector consumption, households increase their labor supply, which accounts for the larger short-run increase in GDP under this scenario and the significant rise in non-tradable production.

In conclusion, there is no simple dichotomy between fiscal and monetary policy, whereby monetary policy can costlessly neutralize the effects of front-loaded government spending on non-tradables, insofar as the resultant private sector crowding-out is undesirable.

\section{B. Saving}

When the government spends the resource revenues, we have seen how macroeconomic volatility ensues, in particular from front-loaded spending, and how monetary policy cannot offset this volatility without cost. We turn now to scenarios in which the government chooses to save a portion of the resource inflows.

\section{Reserve Accumulation}

The set-up for this scenario is precisely that of the previous one. Strictly speaking, the government spends its earnings from the resource inflows. However, one can view the subsequent reserve accumulation policy adopted by central bank as being a form of saving. As we observed in the previous section, if the central bank accumulates reserves without sterilization, the growth in the domestic money supply and ensuing increase in inflation will cause a real appreciation, thus returning us to the negative macroeconomic effects witnessed in the baseline simulation; and if the central bank does sterilize the reserve accumulation, it will eventually crowd out private sector investment. Hence, reserve accumulation as a saving mechanism constitutes at best a partial remedy to the macroeconomic volatility seen under full spending.

\section{The Sovereign Wealth Fund (SWF)}

Having seen how monetary policy can mitigate the effects of Dutch Disease, but at a cost to private sector demand, we now ask whether fiscal policy can avoid such effects without cost. Of course, insofar as front-loaded spending on non-tradables is responsible for Dutch Disease effects in the first place, it may avoid such consequences by smoothing spending

\footnotetext{
${ }^{19}$ This is indicated through two channels. First, the current account deficit expands by less. Second, the reduction in private sector investment reduces the long-run level of output.
} 
intertemporally, as we saw in Scenario 3. We extend this idea to a more sophisticated mechanism where the government can now build up a permanent stock of savings, which in turn enables it to perfectly smooth its spending profile over time, if it chooses to do so, as opposed to the much more limited form of smoothing considered in Scenario 3. To do so, the government now saves a portion of the resource revenues in an offshore SWF that accrues interest at an exogenous rate. Dividend payments are made in the form of transfers. ${ }^{20}$

We specify the operation of the SWF as follows: the government saves a proportion of the revenue inflows that enables the fund to reach a permanently higher level in the detrended equilibrium, and divides the remainder between consumption and investment as per the baseline $\left(\phi^{g c}=0.9, \phi^{g i}=0.1\right)$ and $\left.\phi^{f}=\frac{n \pi^{*}-1}{i^{*}-1}\right)^{21}$. All other assumptions are as per the baseline scenario.

Figure ?? shows the results. The intertemporal smoothing of spending results in much reduced macroeconomic volatility, similar to Scenario 3. Furthermore, as a result of less overall front-loaded spending, the reduced spending on non-tradables further reduces macroeconomic volatility, as discussed in Scenario 2. In effect, the SWF effectively transforms a temporary increase in oil revenues into a permanent, if smaller, revenue stream fed by interest earnings on SWF balances. Hence, fiscal spending under the SWF scenario is sustainable, and the public capital stock will not wither away as it does under the baseline.

Monetary policy challenges are much reduced. Given that most of the oil revenue inflows are saved in an offshore fund, and given the limited macroeconomic pressures from the moderate increase in spending, there would not be much of a rationale for accumulating the remaining foreign exchange inflows as reserves and for pursuing a very tight monetary policy. Hence, monetary and fiscal policy objectives are consistent with each other and the fiscal expansion can take place without triggering a monetary policy response that would lead to a crowding out of the private sector.

In summary, smoothing fiscal spending through an SWF arrangement can support a fiscal strategy that contributes to development through a sustained build up of human and physical capital, makes it possible to calibrate the level of spending such that Dutch Disease effects do not undermine the growth strategy, and avoids macroeconomic pressures that would put monetary policy objectives at risk.

\section{Further Issues}

There are a couple of issues that require singling out. Whilst it would have been entirely possible to discuss them within each scenario, they are of both sufficient complexity and importance to warrant separate discussion.

\footnotetext{
${ }^{20}$ This follows the bird-in-hand rule.

${ }^{21}$ This creates a unit root in the accumulation process.
} 


\section{Current Account}

In both the baseline scenario and the scenario with higher government imports, the current account deficit widens by the same amount. ${ }^{22}$ Furthermore, this amount matches the oil revenue inflows precisely; in other words, full absorption occurs in both cases. It may be intuitive to assume absorption is greater in the case with higher government import, whereas the simulations suggest this is not the case, that is, the degree of absorption is identical in both scenarios. To understand why, we must break the absorption process into two phases. First, government must fully spend the revenue inflows, which happens in both cases. Second, the increase in fiscal spending needs to be "converted" into an increase of the non-oil current account deficit. This means all spending is ultimately converted into imports. In the scenario with a high import share, this happens automatically as the government spends directly on imports. In the baseline, it happens via a two-fold effect of the real appreciation: the appreciation makes imports relatively cheaper, thus increasing demand for tradables, whilst the loss of competitiveness in the domestic tradable sector sees a decline in domestic tradable production. Hence, the increased demand must be met through imports.

However, in Scenario 4, monetary policy blocks both channels, thereby making it impossible for the non-oil current account deficit to rise. Under the baseline, the increase in the non-oil current account deficit allows an equivalent increase in economy-wide absorption (that is, consumption and investment), which means government consumption and investment can rise without crowding out private sector consumption and investment. In the alternative scenario, monetary policy does not allow economy-wide absorption to increase (because it blocks the channels for an increase in the non-oil current account deficit) and consequently an increase in government consumption and investment necessarily results in an equivalent reduction in private sector consumption and investment. This is yet another way of interpreting the existence of private sector crowding-out in this scenario.

\section{Real versus Nominal Exchange Rate}

It is important to make a distinction between the real and nominal exchange rates, what factors determine and affect them and the role they play in the transmission mechanism. The nominal rate is set in the forex market, and as such is controlled by the central bank's reserve management policy. The real rate is controlled by both fiscal and monetary policy in the following sense. An expansionary fiscal policy will tend to lead to a real appreciation that can happen either through a nominal appreciation or through inflation. Whilst the nominal appreciation can be prevented through reserve accumulation by the central bank, to prevent a real appreciation, monetary policy (as distinct from reserve management policy) must also be invoked, which can choose to sterilize the impact of the reserve buildup on money supply. This constitutes a tightening of the monetary policy stance. In a sense, the decision whether

\footnotetext{
${ }^{22}$ Throughout the paper, we use the terms "current account" and "non-oil current account" interchangeably.
} 
to allow the nominal exchange rate to appreciate or not is a nominal decision that in itself has little implication for the real exchange rate; the latter depends on whether monetary policy tightens or not, which is a real decision. Reserve management policy alone does not determine the path of the real exchange rate; rather, it is the combination of reserve management policy and monetary policy (sterilization) that matters for the real exchange rate.

\section{Conclusion}

The purpose of this paper was to calibrate a dynamic micro-founded model and use it to analyze the macroeconomic implications of a surge in resource revenues in PNG by running a suite of policy simulations that could aid policy-makers in determining the most appropriate policy mix. These scenarios were centered around the central question of whether the fiscal authorities should spend or save the revenues accrued from the resource boom.

In short, the conclusions of the simulations may be summarized as follows:

- Fiscal spending on non-tradables is what drives the macroeconomic effects.

- Front-loading of expenditures can lead to macroeconomic volatility, especially if the share of spending on non-tradables is high and there are bottlenecks in the economy.

- Monetary policy cannot undo the effect of counter-productive fiscal policy without cost.

- Saving through reserve accumulation will crowd-out private sector investment.

- Saving in an investment fund can considerably mitigate the adverse macroeconomic effects (at the cost of lower initial development gains as part of the revenue inflows are saved and not invested into the economy).

Of course, the model and the scenarios profess to being neither perfect nor exhaustive. The model entails several shortcomings. A key issue is that by assuming frictionless labor mobility, it fails to realistically model labor migration: in a country such as PNG where education and skill levels are relatively low, labor cannot instantaneously move between sectors, with workers immediately acquiring the requisite skills for their new professions. ${ }^{23}$ The lack of the commercial banking system in the model is another drawback, because in PNG the majority of government deposits are held in commercial banks, rather than the central bank. Indeed, this structural characteristic of the PNG monetary economy has been at the center of a major policy challenge for the Bank of PNG that cannot be addressed by the model used here: even though the fiscal authorities have been saving a sizable part of the resource revenues accrued during the commodity price boom over the last decade or so, these

\footnotetext{
${ }^{23}$ This was discussed in Section 3
} 
deposits have been placed at commercial banks and have therefore had a significant impact on the domestic money supply. The Bank of PNG subsequently issued significant volumes of Central Bank Bills (CBBs) in order to sterilize this buildup of excess liquidity, which contradicts the model prediction that sterilization should be unnecessary if natural resource revenue inflows are saved. ${ }^{24}$ However, given that the model is already fairly large, adding more sectors or institutional details is not necessarily the way forward, because this would increase the complexity of the model, making it more difficult for users to arrive at sensible interpretations of the results. Finally, it needs to be stressed that this model should be used only for qualitative analysis, not quantitative forecasts. This reflects the above-mentioned shortcomings as well as uncertainty regarding the parameter calibration; estimating the model is not an option because the data required to do so simply does not exist.

Before discussing the research agenda going forward, it is useful to sketch out how the present model fits into the modeling toolkit for PNG. On the one hand, it complements computational general equilibrium (CGE) models for PNG that are being maintained by the Bank of PNG and the Department for National Planning and Monitoring. ${ }^{25}$ These models have a much richer sectoral structure than the model used here, but they do not model the macroeconomic adjustment process in much detail, which implies they have a medium- to long-term modeling horizon whereas the present model has a short- to medium-term horizon. On the other hand, research is currently under way to create a smaller New Keynesian model, based on the Forecasting and Policy Analysis System (FPAS) approach that can be estimated for PNG. ${ }^{26}$ The aim is for this model to produce forecasts of a quantitative as well as qualitative nature. Given that the FPAS model has much less detail than the model used here, these models are also complementary to each other. Going forward, the research agenda will aim for two objectives: the first is to use the present model for investigating other policy questions such as the impact of Dutch Disease effects with a large value of the learning-by-doing parameter, in which case the real appreciation and shrinkage of the tradable sector observed in many simulations in this paper will have a substantial adverse impact on overall growth prospects. The second objective is completing the FPAS model and putting it to work as a tool that complements the financial programming framework for PNG.

\footnotetext{
${ }^{24}$ See the September 2011 Monetary Policy Statement by the Bank of Papua New Guinea, page 7 paragraph 2, and Chart 5: http://www.bankpng.gov.pg/images/stories/MPS/2011/Sep_l1_MPS_Final.pdf

${ }^{25}$ see Dixon et al. (2010).

${ }^{26}$ See Berg et al. (2006).
} 

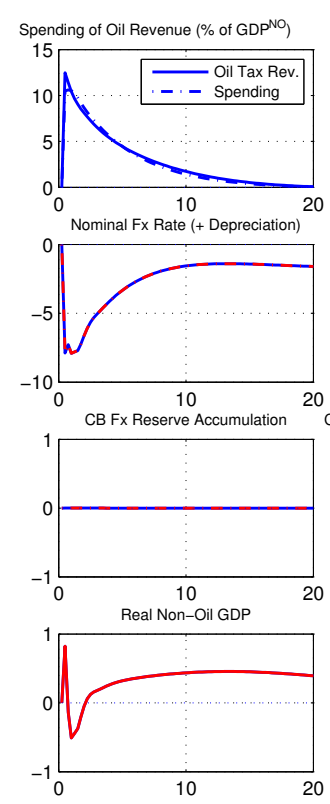
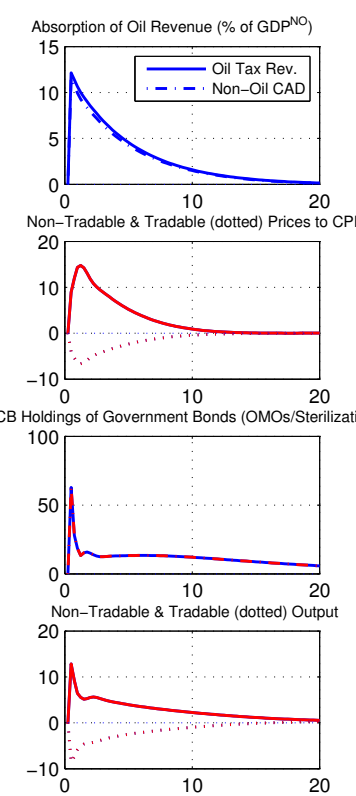
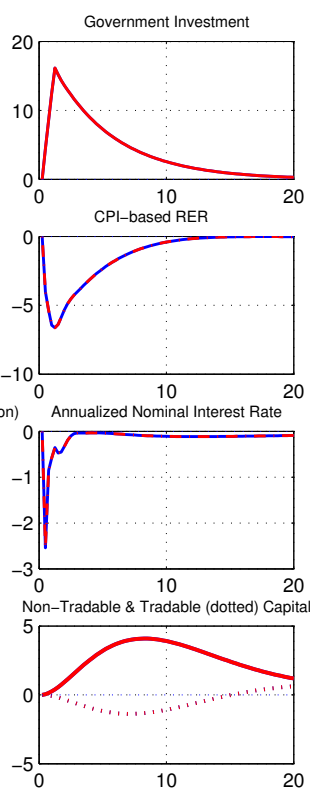
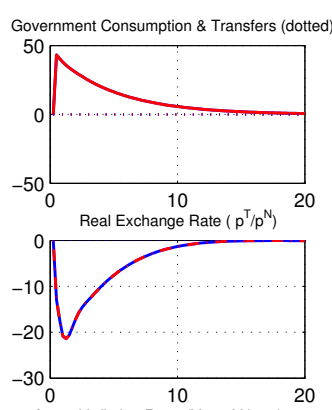

Annual Inflation Rate ( $Y$-to-Y $Y$ in \%)
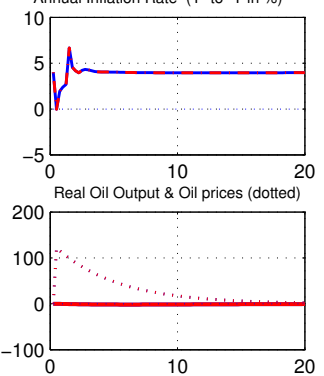

Figure 2. Baseline Scenario: Summary of Results
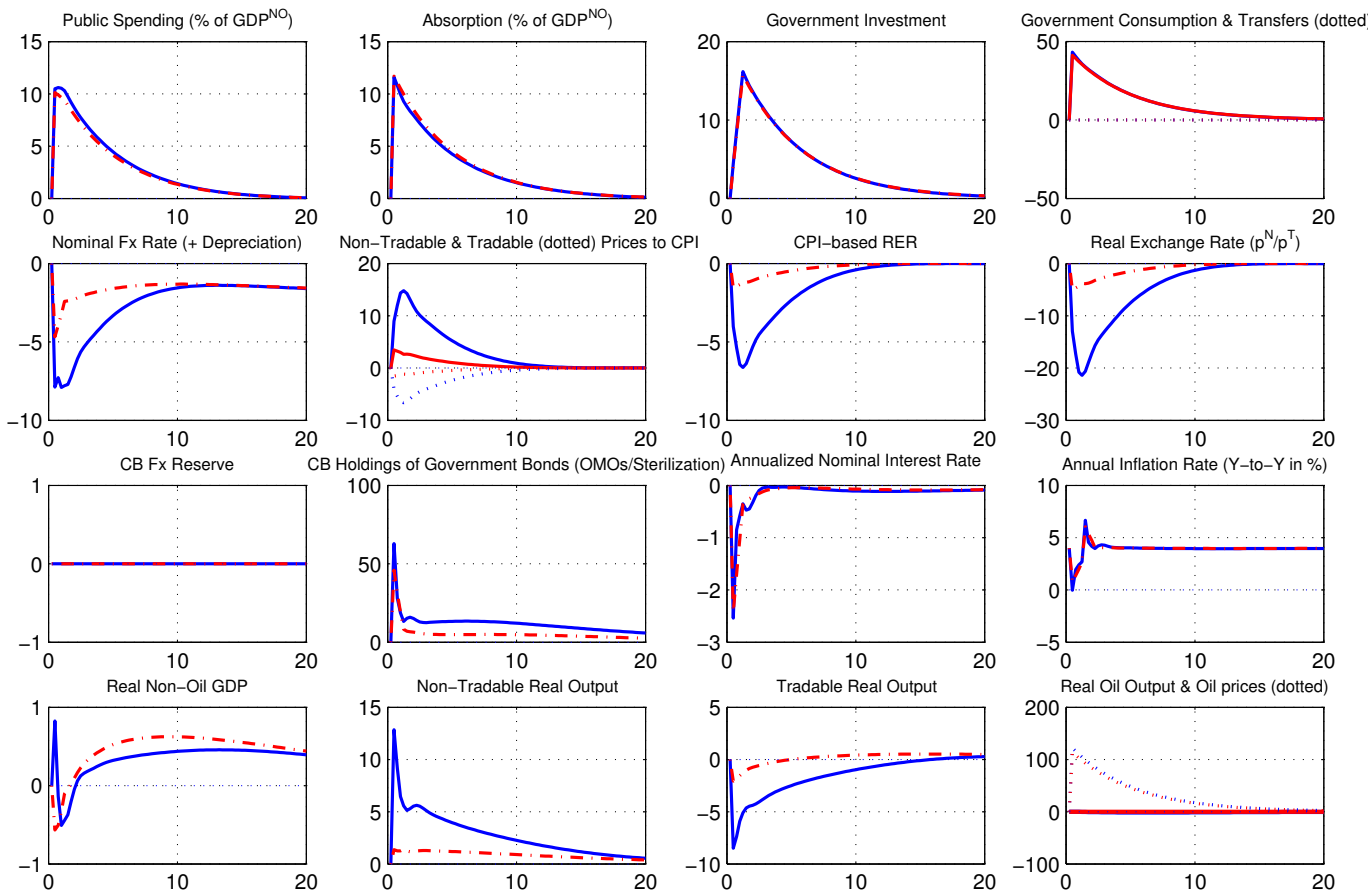

- High Non-Tradable Share

. High Import Share

Figure 3. Scenario 2: Summary of Results 

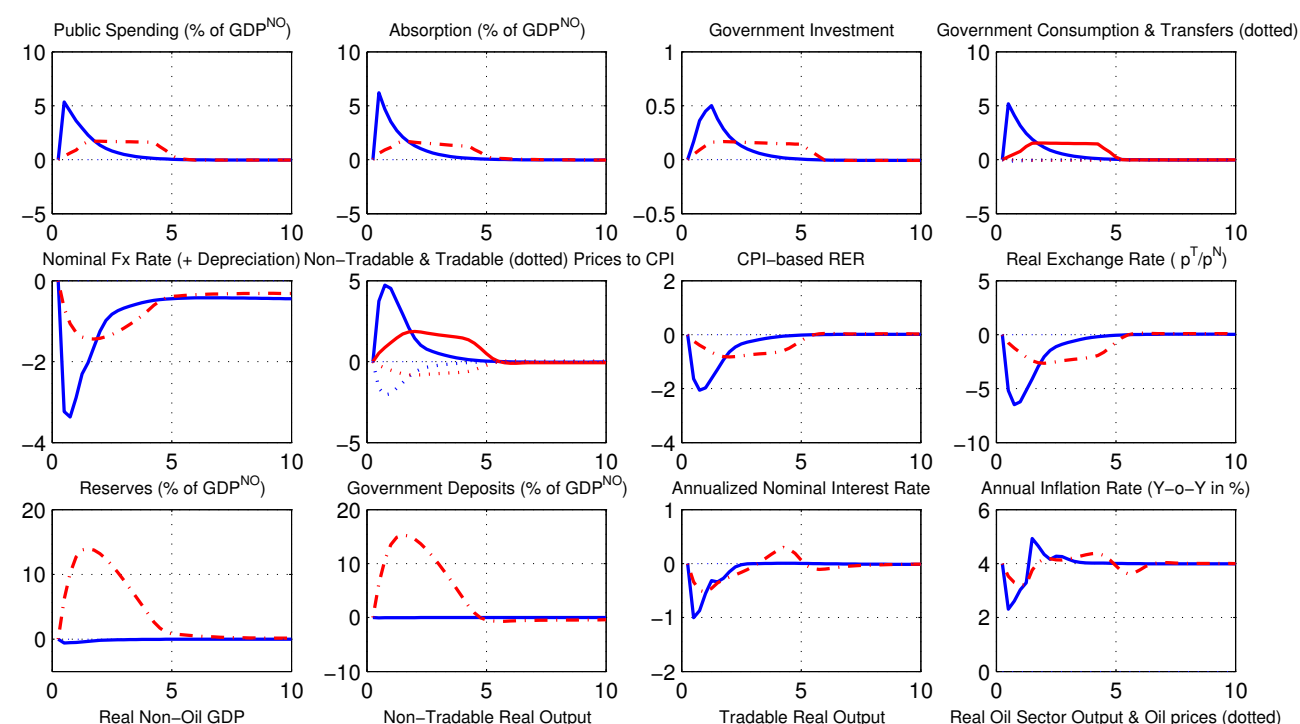

Annualized Nominal Interest Rate

Annual Inflation Rate ( $\mathrm{Y}-\mathrm{o}-\mathrm{Y}$ in \%)
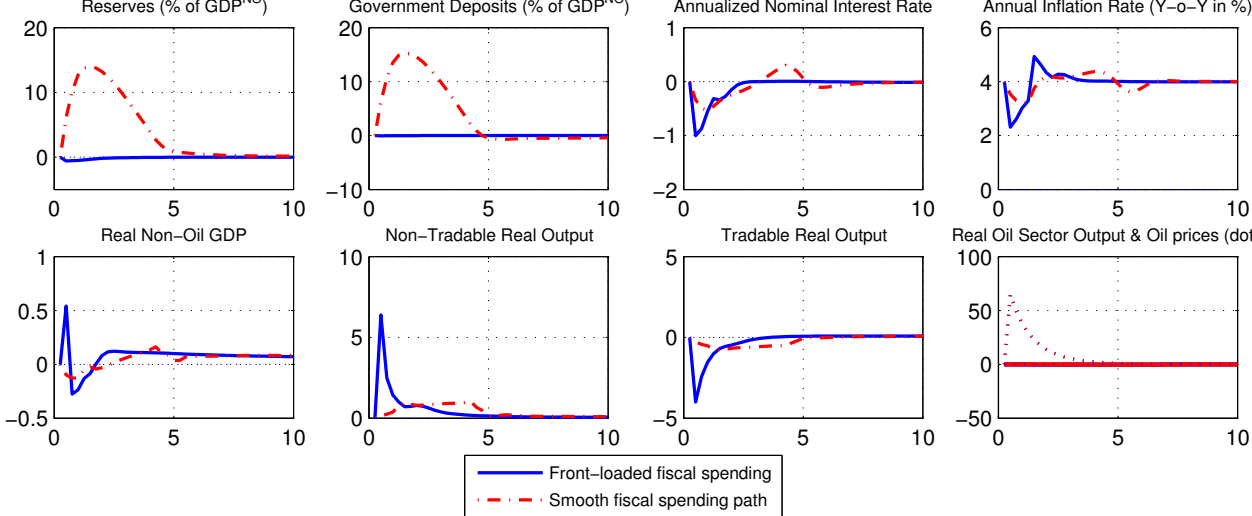

Real Oil Sector Output \& Oil prices (dotted)

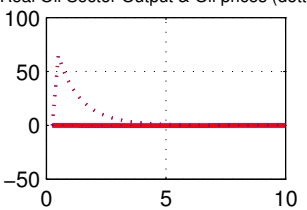

Figure 4. Scenario 3: Summary of Results
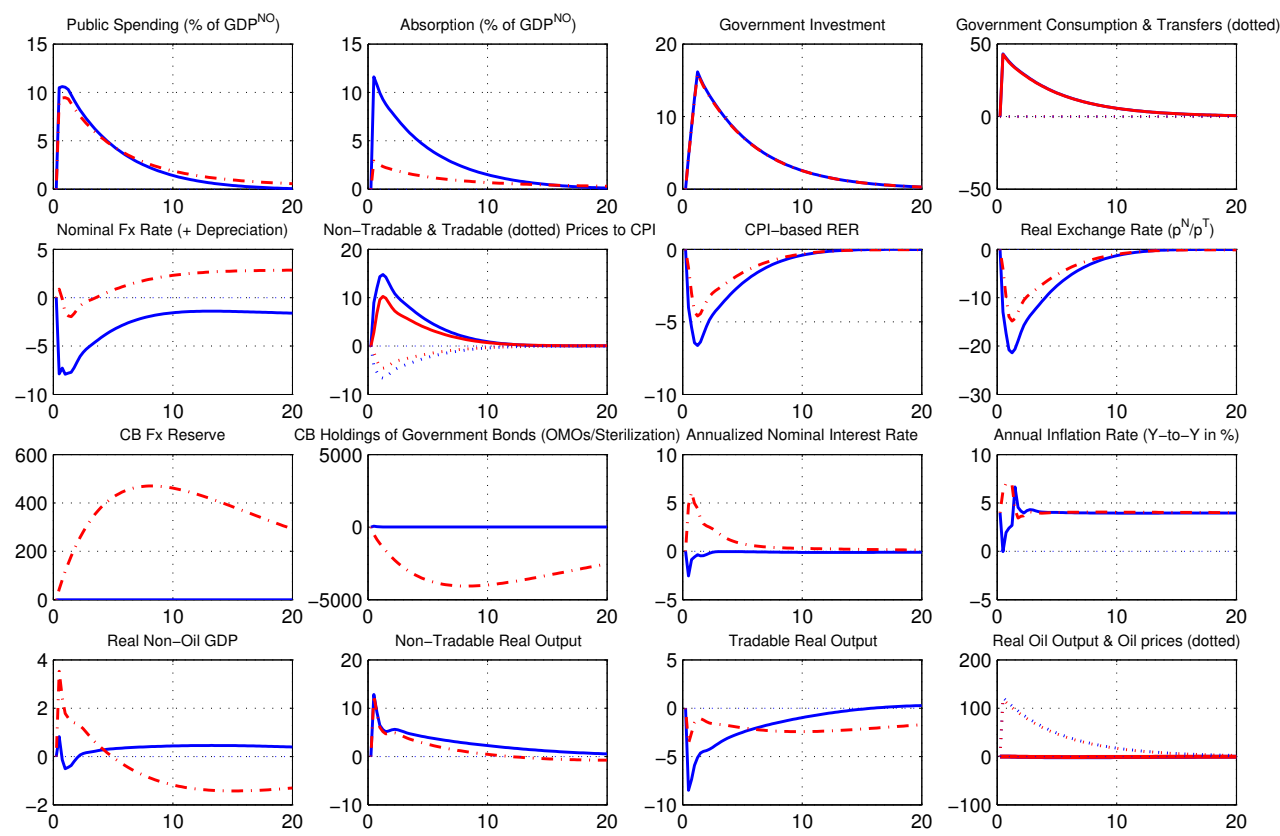

Figure 5. Scenario 4: Summary of Results 

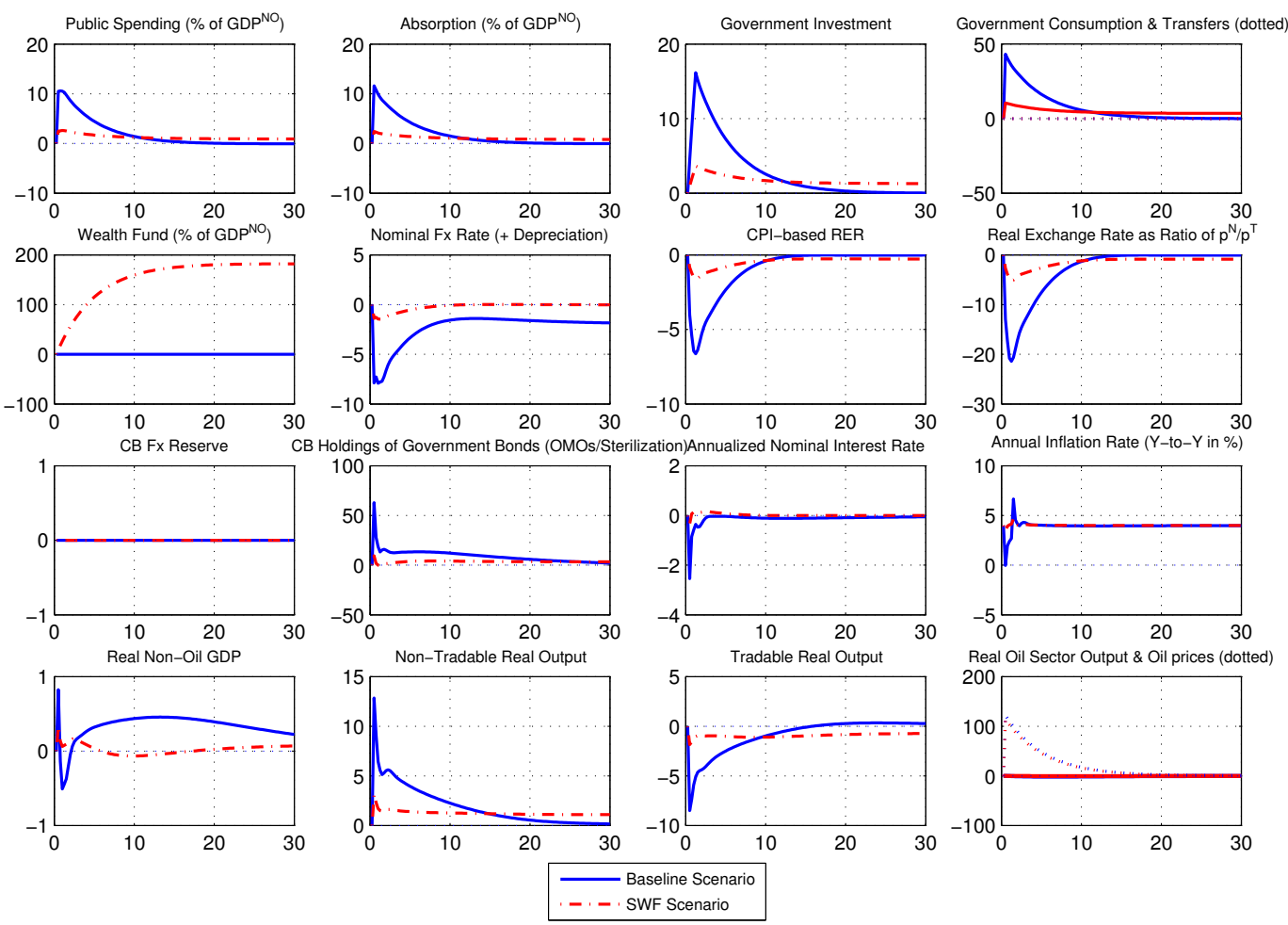

Figure 6. Scenario 5: Summary of Results 


\begin{tabular}{llll}
\hline \hline Parameters & Values & Notes & Source/Description \\
\hline$\alpha^{T}, \alpha^{N}$ & 0.7 & labor income shares & \\
$\alpha^{G}$ & 0.1 & elasticity of output wrt public capital & based on Arslanalp et al. (2010) \\
$d$ & 0.1 & learning in the traded sector & small Dutch Disease effects \\
$\rho_{z}$ & 0.1 & persistence in lbd disturbance & \\
$\kappa^{N}, \kappa^{T}$ & 25 & investment adjustment cost & ensures smooth investment adjustment \\
$\delta^{N}, \delta^{T}$ & 0.015 & depreciation rate for $K^{N}$ and $K^{T}$ & \\
$\nu$ & 10000 & portfolio adjustment cost & implies closed capital account \\
\hline \hline
\end{tabular}

Table 1. Technology Parameters

\begin{tabular}{|c|c|c|}
\hline Parameters & Values & Notes (source/description) \\
\hline$\varphi$ & 0.3 & degree of home bias in consumption (computed using national accounts data) \\
\hline$\chi$ & 0.89 & $\begin{array}{l}\text { elasticity of substitution between traded and non-traded sectors } \\
\text { (Berg et al. (2010)) }\end{array}$ \\
\hline$\theta$ & 12 & $\begin{array}{l}\text { elasticity of substitution between varieties-related to mark-up power } \\
\text { (Berg et al. (2010)) }\end{array}$ \\
\hline$\psi^{a}$ & 2.5 & inverse of Frisch elasticity of labor supply, savers (Berg et al. (2010)) \\
\hline$\psi^{h}$ & 10 & $\begin{array}{l}\text { inverse of Frisch elasticity of labor supply, hand-to-mouth } \\
\text { (large value to prevent big income effect) }\end{array}$ \\
\hline$\sigma$ & 2 & $\begin{array}{l}\text { inverse of the intertemporal elasticity of substitution for consumption } \\
\text { (Berg et al. (2012b)) }\end{array}$ \\
\hline$\eta$ & 0.38 & $\begin{array}{l}\text { interest semi-elasticity of money demand } \\
\text { (chosen to obtain reasonably smooth interest rate) }\end{array}$ \\
\hline$\delta$ & 0.43 & $\begin{array}{l}\text { labor share in non-traded sector } \\
\text { (computed from production parameters and size of non-tradable sector) }\end{array}$ \\
\hline$\rho$ & 1 & elasticity of substitution between the two types of labor (Berg et al. (2010)) \\
\hline$\beta^{a}$ & 0.99506 & $\begin{array}{l}\text { quarterly discount factor } \\
\text { (computed as a function of growth, inflation and interest rates) }\end{array}$ \\
\hline $\mathfrak{p}$ & 0.5 & measure of savers \\
\hline
\end{tabular}

Table 2. Preference Parameters 


\begin{tabular}{lll}
\hline \hline Parameters & Values & Notes \\
\hline$\iota_{C}$ & 49.4 & consumption $/ G D P * 100$ \\
$\iota_{C T}$ & 34.1 & consumption of traded goods $/ G D P * 100$ \\
$\iota_{C N}$ & 15.3 & consumptionof non-traded goods/GDP*100 \\
$\iota_{I}$ & 16.0 & investment $/ G D P * 100$ \\
$\iota_{G D P_{o}}$ & 29.8 & mining value added $/ G D P * 100$ \\
$\iota_{G}$ & 21.0 & government spending $/ G D P * 100$ \\
$\iota_{G C}$ & 16.1 & government consumption $/ G D P * 100$ \\
$\iota_{G I}$ & 4.9 & government investment/GDP*100 \\
$\iota_{G T}$ & 9.1 & government spending on traded goods $/ G D P * 100$ \\
$\iota_{G N T}$ & 11.9 & government spending on non-traded goods $/ G D P * 100$ \\
$\iota_{E X}$ & 68.9 & exportt/GDP*100 \\
$\iota_{M}$ & 13.1 & real money balances/GDP $/ 100$ \\
$\iota_{B}$ & 3.0 & private sector's net foreign assets $/ G D P * 100$ \\
$\iota_{r e s}$ & 13.8 & central bank foreign reserves/GDP*100 \\
$\iota_{D g}$ & 2.3 & govt deposits at the CB $/ G D P * 100$ \\
$\iota_{F}$ & 0.1 & govt wealth fund or foreign assets $/ G D P * 100$ \\
$\iota_{B c}$ & 30 & govt debt private sector/GDP*100 \\
$\iota_{A}$ & 6.1 & aid/GDP $* 100$ \\
$\rho_{a}$ & 0.95 & persistence for aid process \\
\hline \hline
\end{tabular}

Table 3. National Accounts Steady State Values 


\section{REFERENCES}

S. Arslanalp, F. Bornhorst, S. Gupta, E. Sze, 2010, "Public Capital and Growth," IMF Working Papers, No. 10/175, International Monetary Fund, Washington, D.C.

M. Baxter, R. G. King, 1993, "Fiscal Policy in General Equilibrium," American Economic Review, Vol. 86, pp. 1154-1174.

A. Berg, C. Conceição, J. S. Lizondo, M. Gaertner, J. Gottschalk, B. E. House, A. F. Odusola, R. Portillo, L. Redifer, L.-F. Zanna, 2012, "Enhancing Development Assistance to Africa: Lessons from scalingup Scenarios," IMF 2012.

A. Berg, J. Gottschalk, R. Portillo, L-F. Zanna, 2010, "The Macroeconomics of Medium-Term Aid scalingup Scenarios," IMF Working Papers, No. 10/160, International Monetary Fund, Washington, D.C.

A. Berg, R. Portillo, S-C. S. Yang, L-F. Zanna, 2013, "Public Investment in Resource-Abundant Developing Countries," IMF Economic Review (forthcoming).

A. Berg, P. Karam, D. Laxton, 2006, "A Practical Model-Based Approach to Monetary Policy Analysis: A How-To Guide,” IMF Working Papers, No. 06/081, International Monetary Fund, Washington, D.C.

J. Y. Campbell, N. G. Mankiw, 1989, "Consumption, Incomes, and Interest Rates:

Reinterpreting the Time Series Evidence,” NBER Macroeconomics Annual 1989, ed. by O. J. Blanchard, and S. Fischer, pp. 185-216. MIT Press.

P. Dixon, G. Kauzi, M T. Rimmer, 2010, "Effects on the PNG Economy of a Major LNG Project," Economic Society of Australia, 2010, Vol. 29 No. 2.

C. Kamps, 2004, “The Dynamic Macroeconomic Effects of Public Capital,” Springer 2004, Berlin, Germany.

F. Kydland, E. C. Prescott, 1982, "Time to Build and Aggregate Fluctuations," Econometrica, 1982, Vol. 50, pp. 1345-1370.

E. M. Leeper, T. B. Walker, S-C. S. Yang, 2010, "Government Investment and Fiscal Stimulus," Journal of Monetary Economics, 2010, Vol. 58, No. 8, pp. 1000-1012.

N. G. Mankiw, 2000, "The Savers-Spenders Theory of Fiscal Policy," American Economic Review Papers and Proceedings, May 2000, pp. 120-125.

F. van der Ploeg, 2011, "Natural Resources: Curse or Blessing," Journal of Economic Literature, Vol. 49, No. 2, pp. 366-420.

L. Pritchett, 2000, "The Tyranny of concepts: CUDIE (Cumulated, Depreciated, Investment Effort) Is Not Capital," Journal of Economic Growth, Vol. 4, No. 4, pp. 361-384.

S. Schmitt-Grohe, M. Uribe, 2003, "Closing Small Open Economy Models," Journal of International Economics, Vol. 61, No. 1, pp. 163-185. 


\section{Appendix I. Optimality Conditions}

This appendix contains the first order conditions of all the optimization problems in the model. Let $\lambda_{t}, \lambda_{t}^{N}$, and $\lambda_{t}^{T}$ be the Lagrangian multipliers for the maximization problems of households, non-traded firms, and traded firms. Define the Tobin's q as $q_{t}^{N}=\frac{\lambda_{t}^{N}}{\lambda_{t}}$ and $q_{t}^{T}=\frac{\lambda_{t}^{T}}{\lambda_{t}}$.

$$
\begin{aligned}
& \lambda_{t}\left(1+\tau_{t}^{c}\right)=\left(c_{t}\right)^{-\sigma} \\
& \lambda_{t}=\beta E_{t}\left(\lambda_{t+1} R_{t}\right) \\
& \kappa\left(l_{t}\right)^{\psi}=\lambda_{t}\left(1-\tau_{t}^{l}\right) w_{t} \\
& \lambda_{t}^{N}=\beta E_{t}\left\{\frac{\lambda_{t+1}}{\lambda_{t}}\left[\left(1-\delta^{N}\right) \lambda_{t+1}^{N}+\left(1-\alpha^{N}\right)(1-\iota) p_{t+1}^{N} \frac{y_{t+1}^{N}}{k_{t}^{N}}\right]\right\} \\
& l_{t}^{N}=\delta\left(\frac{w_{t}^{N}}{w_{t}}\right)^{\rho} l_{t} ; \quad l_{t}^{T}=\delta\left(\frac{w_{t}^{T}}{w_{t}}\right)^{\rho} l_{t} \\
& \frac{1}{q_{t}^{N}}=1-\frac{\kappa^{N}}{2}\left(\frac{i_{t}^{N}}{i_{t-1}^{N}}-1\right)^{2}-\kappa^{N}\left(\frac{i_{t}^{N}}{i_{t-1}^{N}}-1\right) \frac{i_{t}^{N}}{i_{t-1}^{N}}+\beta \kappa_{N} E_{t}\left\{\frac{q_{t+1}^{N} \lambda_{t+1}}{q_{t}^{N} \lambda_{t}}\left(\frac{i_{t+1}^{N}}{i_{t}^{N}}-1\right)\left(\frac{i_{t+1}^{N}}{i_{t}^{N}}\right)^{2}\right\} \\
& l_{t}^{N}=\left[\frac{\alpha^{N}(1-\iota) p_{t}^{N} z^{N}\left(k_{t-1}^{N}\right)^{1-\alpha^{N}}\left(K_{t-1}^{G}\right)^{\alpha^{G}}}{w_{t}^{T}}\right]^{\frac{1}{1-\alpha^{N}}} \\
& \lambda_{t}^{T}=\beta E_{t}\left\{\frac{\lambda_{t+1}}{\lambda_{t}}\left[\left(1-\delta^{T}\right) \lambda_{t+1}^{T}+\left(1-\alpha^{T}\right)(1-\iota) s_{t+1} \frac{y_{t+1}^{T}}{k_{t}^{T}}\right]\right\} \\
& l_{t}^{T}=\left[\frac{\alpha^{T}(1-\iota) s_{t} z_{t}^{T}\left(k_{t-1}^{T}\right)^{\alpha^{T}}\left(K_{t-1}^{G}\right)^{\alpha^{G}}}{w_{t}^{T}}\right]^{\frac{1}{1-\alpha^{T}}} \\
& \frac{1}{q_{t}^{T}}=1-\frac{\kappa^{T}}{2}\left(\frac{i_{t}^{T}}{i_{t-1}^{T}}-1\right)^{2}-\kappa^{T}\left(\frac{i_{t}^{T}}{i_{t-1}^{T}}-1\right) \frac{i_{t}^{T}}{i_{t-1}^{T}}+\beta \kappa_{T} E_{t}\left\{\frac{q_{t+1}^{T} \lambda_{t+1}}{q_{t}^{T} \lambda_{t}}\left(\frac{i_{t+1}^{T}}{i_{t}^{T}}-1\right)\left(\frac{i_{t+1}^{T}}{i_{t}^{T}}\right)^{2}\right\}
\end{aligned}
$$

